Article

\title{
Energy Recovery of Shrub Species as a Path to Reduce the Risk of Occurrence of Rural Fires: A Case Study in Serra da Estrela Natural Park (Portugal)
}

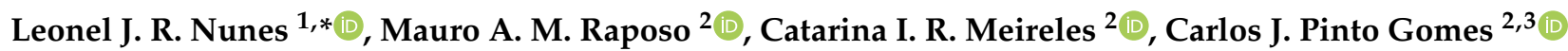 \\ and Nuno M. C. Almeida Ribeiro ${ }^{4,5}$ (B) \\ 1 Unidade de Investigação em Materiais, Energia e Ambiente Para a Sustentabilidade, Escola Superior Agrária, \\ Instituto Politécnico de Viana do Castelo, Rua da Escola Industrial e Comercial de Nun'Alvares, \\ 4900-347 Viana do Castelo, Portugal \\ 2 Mediterranean Institute for Agriculture, Environment and Development, Pólo da Mitra, Universidade de \\ Évora, 7006-554 Évora, Portugal; mraposo@uevora.pt (M.A.M.R.); cmeireles@uevora.pt (C.I.R.M.); \\ cpgomes@uevora.pt (C.J.P.G.) \\ 3 Departamento da Paisagem, Ambiente e Ordenamento, Universidade de Évora, 7000-671 Évora, Portugal \\ 4 Instituto de Ciências da Terra, Universidade de Évora, Rua Romão Ramalho, 59, 7002-554 Évora, Portugal; \\ nmcar@uevora.pt \\ 5 Departamento de Fitotecnia, Universidade de Évora, 7000-083 Évora, Portugal \\ * Correspondence: leonelnunes@esa.ipvc.pt; Tel.: +351-258-909-740
}

check for

updates

Citation: Nunes, L.J.R.; Raposo, M.A.M.; Meireles, C.I.R.; Gomes, C.J.P.; Ribeiro, N.M.C.A. Energy Recovery of Shrub Species as a Path to Reduce the Risk of Occurrence of Rural Fires: A Case Study in Serra da Estrela Natural Park (Portugal). Fire 2021, 4, 33. https://doi.org/ $10.3390 /$ fire 4030033

Academic Editor: Alistair M. S. Smith

Received: 27 May 2021

Accepted: 30 June 2021

Published: 30 June 2021

Publisher's Note: MDPI stays neutral with regard to jurisdictional claims in published maps and institutional affiliations.

Copyright: (c) 2021 by the authors. Licensee MDPI, Basel, Switzerland. This article is an open access article distributed under the terms and conditions of the Creative Commons Attribution (CC BY) license (https:// creativecommons.org/licenses/by/ $4.0 /)$.

\begin{abstract}
The accumulation of biomass fuels resulting from the growth of heliophilous shrubs and small tree species at the edge of forests and on scrub and pasture lands contributes to the increased risk of rural fires in Mediterranean climate regions. This situation has been managed with a set of legislative measures launched with the objective of promoting cleaning and the control of these species. Areas of scrub and pasture already constitute the largest part of the annually burnt area in Portugal, resulting in high-intensity fires. In the present study, shrubs and small tree species were characterized in the laboratory. Thermogravimetric, chemical and calorimetric analyses for the evaluation of the potential for the energy recovery of the selected species were carried out. It was observed that energetic valorization (i.e., to enhance the value by planned actions) of these species is difficult because they present high levels of ash and metals, becoming prone to the occurrence of fouling and slagging phenomena. Thus, the creation of value chains that justify the incorporation of these materials becomes very difficult, except if used in non-certified, small-scale and locally based processes. The possibility of recovery through thermochemical conversion processes, such as torrefaction, pyrolysis or gasification, must be studied so that more efficient and feasible recovery alternatives can be found, allowing for the creation of value chains for these residual materials to promote their sustainable management and, thus, mitigate the risk of rural fires occurring.
\end{abstract}

Keywords: rural fires; shrub species; energy recovery; residual biomass

\section{Introduction}

Humanity is currently facing one of its greatest challenges with the occurrence of severe anomalous phenomena caused by climate change [1]. This situation led to a collective awareness at the same time that scientific information on the subject was disseminated by the media mostly as an explanatory note of some reported events [2]. The forms of mitigation presented include the elimination, or rather the attempt to reduce, the levels of carbon dioxide $\left(\mathrm{CO}_{2}\right)$ in the atmosphere, since this greenhouse gas is considered to be the main cause of climate change [3]. One way to reduce $\mathrm{CO}_{2}$ content is through the substitution of fossil origin energy by renewable energy, since this substitution avoids the return of carbon captured in past geological times to the actual atmosphere [4]. This carbon 
was already out of the current carbon cycle, since it was captured by plants and phytoplankton in ancient geological past periods and sequestered in geological formations [5]. Thus, biomass is an alternative, since, although its use is not exempt from $\mathrm{CO}_{2}$ emissions, its release is considered neutral [6]. In other words, this $\mathrm{CO}_{2}$ released, for example, by the combustion of firewood, is equivalent to what the biomass sequestered during its lifetime, which certainly occurred during the current carbon cycle [7].

However, not all biomass presents the ideal characteristics to be energetically valued [8]. In fact, biomass presents a number of disadvantages that are well known, namely, its low density, high moisture content, high inert load and low energy potential [9]. This is the main reason that prevented the incorporation of shrubs and herbaceous biomass in supply chains for energy [10]. It must be noted that these herbaceous and shrub species can provide large amounts of biomass, with high yields per hectare. There is also motivation for incorporating these low-cost raw materials into supply chains because they are responsible for the accumulation of large fuel loads that increase the risk of fire in forests and pastures [11]. This perspective can contribute to solve the environmental problem caused by the increase in rural fire risk during the hottest and driest periods, common in Mediterranean climates [12]. The use of materials resulting from forest and pasture land management operations is a possibility, especially if it creates value chains that can contribute to the sustainability of such operations [13]. In a recent past, these materials were used to accommodate livestock or for the production of manure, contributing to a reduction in fuel load. However, currently, these waste materials are not subject to any type of use [14].

With the decline in the use of traditional agro-silvo-pastoral activities remains the need to control the vegetation by other means, periodic and always onerous, in which the final treatment of the materials is usually the burning of the leftovers [15], in other words, the combustion of residual materials in the forest or in the pasture without any use for energy, with the release of $\mathrm{CO}_{2}$ and potentially causing the onset of rural fires [16]. This situation is the main cause of rural fires in Portugal [17]. This fuel load management is a problem for private owners who avoid cleaning due to the difficulty in supporting the costs, despite it being mandatory by law—namely, by Decree-Law no. 124/28 June 2006. This legislation requires that landowners are obliged to proceed with fuel load management by 30 April of each year.

The possibility of valuing these residues in biomass power plants has never effectively materialized, since the logistical difficulties associated with the low density and dispersion of the materials almost always make the feasibility of the task impossible. Additionally, the low heating value that this biomass presents, combined with other parameters, such as the high ash content and inert load, jeopardizes the efficiency of the combustion in biomass power plants, forcing the use of roundwood. In other words, national legislation, namely, the Resolution of the Council of Ministers no. 114/15 September 2006, which presented the National Strategy for Forests, emphasized the economic, social and environmental importance that the forest sector represents for national development, and underlined the relevance of the collection of forest biomass as a way to reduce the risk of rural fires.

The articulation between the National Strategy for Forests with the National Energy Strategy, as stated in the Resolution of the Council of Ministers no. 29/15 April 2010, presented the conducting lines for the sustainable management of resources, contributing to the achievement of the objectives assumed for the energy sector, and imposed special attention to biomass energy recovery. This was reinforced with the update of the National Action Plan for Renewable Energies (PNAER), approved by the Resolution of the Council of Ministers no. 20/10 April 2013, which establishes the creation of a decentralized network of biomass power plants, and with the consequent reinforcement of the installed capacity, as well as with the publication of Decree-Law no. 64/12 June 2017, where the use and enhancement of forest biomass is promoted. 
In this sense, the Resolution of the Council of Ministers no. 81/3 November 2010, established some measures to ensure long-term sustainability in the supply of biomass power plants, as well as to make their construction and exploration effective, associating the achievement of these objectives with the application of economic incentives. In this context, Decree-Law no. 5/10 January 2011, promotes the use of biomass to guarantee the supply of the power plants, establishing a legal regime for biomass valorization. To make viable the construction of biomass power plants and the investments in progress, Decree-Law no. 48/12 April 2019, established the extension of the deadline for the entry into operation of biomass power plants under construction and also fixed a discount of $5.0 \%$ to the applicable tariff for each month that elapsed after 31 December 2018 or, in cases where the production license had to be preceded by an environmental impact assessment, after 31 December 2019, until the new deadlines now set for entry into operation are reached. In addition to the possibility of using biomass power plants, the incorporation of these residual materials in the production of wood pellets was also a hypothesis [18]. However, for the same reasons associated with the quality of the materials, producers avoided their inclusion, especially when wood pellets are certified according to international standards, such as the ENplus ${ }^{\circledR}$, which regulates the permissible limits of a set of criteria, such as ash or chemical elements, which determine the behavior during combustion, namely, by increasing the propensity for the occurrence of corrosion, slagging and fouling phenomena [19].

For these reasons, the possibility of valuing residual biomass is conditioned, both by the quality and, mainly, due to the lack of knowledge of the characteristics of many of the species included in this study. Thus, the main objective of the present study was to conduct a survey of the most abundant species of shrub and small trees species, responsible for a large part of the accumulation of fuel load in Portugal. Their characterization from the perspective of assessing their potential for energy recovery was conducted, through the identification of the most critical parameters.

\section{Materials and Methods}

\subsection{Location of the Area Selected for Sampling}

The Serra da Estrela Natural Park justifies its creation because it is a region with a typical mountain economy and due to the need to preserve the existing wildlife refuges and endemic plant formations, which are unique in the national context and shared by the municipalities of Celorico da Beira, Covilhã, Gouveia, Guarda, Manteigas and Seia [20]. The mountain range is characterized as a large orographic accident, which, together with Serra do Açor and Serra da Lousã, constitutes the westernmost part of the central Iberian mountain range [21]. The landscape of the region is divided into different forms, namely, the central plateau, the peaks, the lower plateaus, the slopes and the valleys, where the water lines that form part of the main hydrographic basins run, specifically the Mondego and Tejo rivers [22]. However, despite the fluvial component having an important role in the geomorphology of the region, in the upper part of the mountain range are traces of the influence of quaternary glaciation [23]. Figure 1 shows the location of the area selected for sampling. 

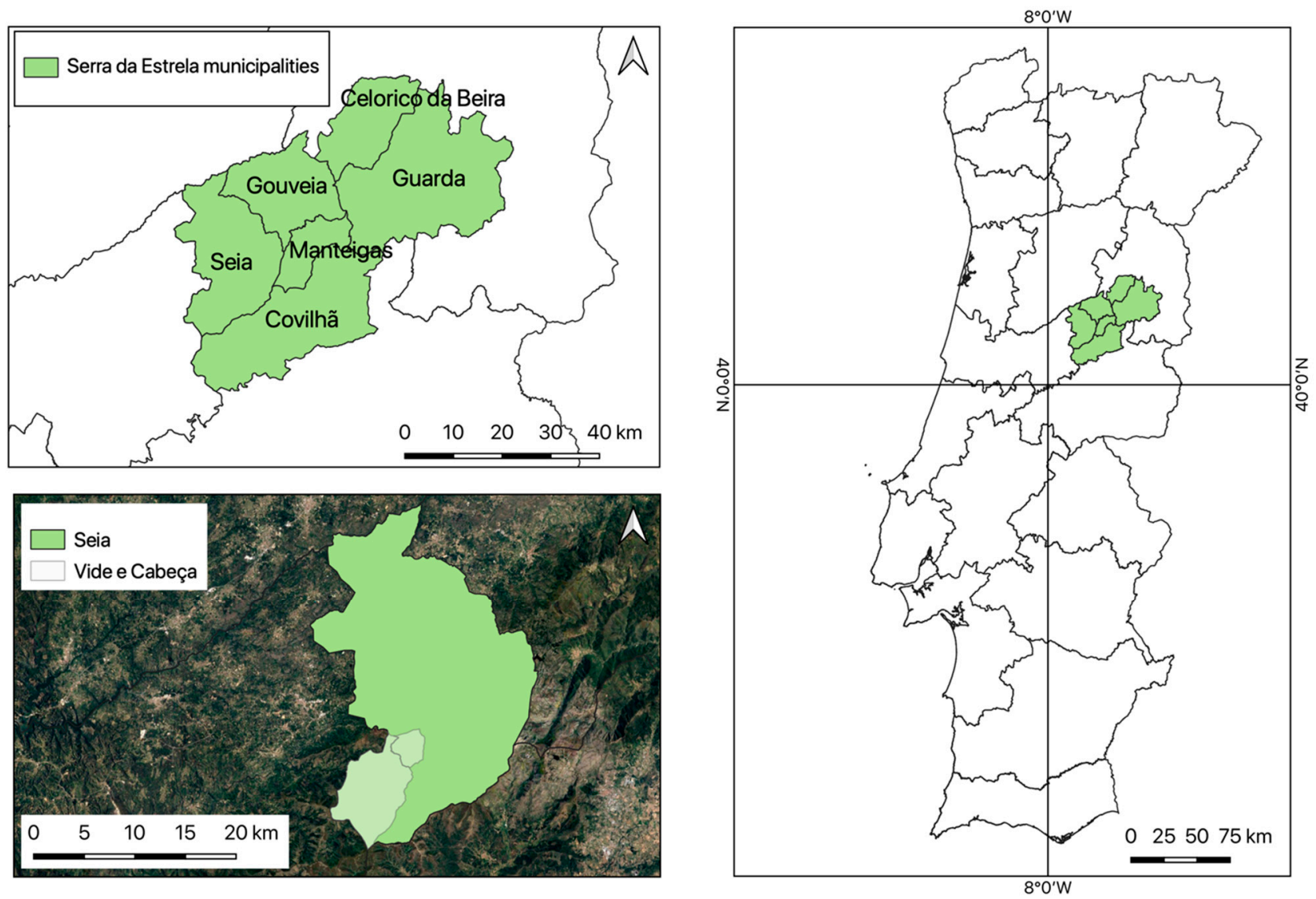

Figure 1. Location of the area selected for sample collection.

\subsection{Framework of the Regional Flora}

The geographical location of Serra da Estrela and its relative proximity to the Atlantic Ocean allows for the influence of the Mediterranean, Atlantic and continental climate types, which, together with other regional characteristics, such as orography and geology, led to the development of high biodiversity patterns [24]. This diversity is also increased by the variation caused by the altitude of the mountain, which delimits three zones or floors of vegetation in response to altitude [25]. The first floor starts at the foot of the mountain and extends up to 800 or $900 \mathrm{~m}$, where Quercus rotundifolia and Quercus suber stands predominate on the south-facing slopes, while on the north-facing slopes, Quercus robur stands predominate. Stands of Fraxinus angustifolia, Alnus glutinosa, Salis sp., Ulmus minor and Prunus lusitanica are found in the most humid areas, usually along water lines. Between 800 and $1800 \mathrm{~m}$, the dominant populations are composed of Quercus pyrenaica and Quercus rotundifolia on the south-facing slopes, while on the west-facing slopes, Quercus pyrenaica stands dominate. Betula alba and Taxus baccata stands in the most humid regions were destroyed by rural fires and by agro-silvo-pastoral practices, which led to these forests being gradually replaced by stands of Erica sp., Calluna vulgaris, Cytisus sp., Genista sp. and Echinospartum sp. and by meadows, when the degradation was even more intense. Above $1800 \mathrm{~m}$, the vegetation is least developed, being formed by several types of shrubs [26-29]. 


\subsection{Selection and Collection of Samples}

The Serra da Estrela region comprises a set of specificities of a climatic nature, soils and ecosystems, justifying its in-depth study. In order to carry out this study, an inventory of native shrub and small tree species in the Casal do Rei area was conducted. Later, the species were classified as being heliophilous or not, and the dominant species within this group were identified. The identification of heliophilous and dominant species was carried out with bibliographic analysis. The results of this classification are shown in Table 1.

Table 1. Samples collected for the characterization tests.

\begin{tabular}{|c|c|c|}
\hline Species Latin Name & Heliophilous Species & Dominant Species \\
\hline Adenocarpus cumplicatus & $x$ & \\
\hline \multicolumn{3}{|l|}{ Arbutus unedo } \\
\hline Calluna vulgaris & $x$ & $x$ \\
\hline Cistus populifolius & $x$ & \\
\hline Cistus psilosepalus & $x$ & $\mathrm{x}$ \\
\hline Cistus salviifolius & $x$ & $x$ \\
\hline \multicolumn{3}{|l|}{ Crataegus monogyna } \\
\hline Cytisus multiflorus & $\mathrm{x}$ & $\mathrm{x}$ \\
\hline Cytisus striatus & $x$ & $x$ \\
\hline \multicolumn{3}{|l|}{ Daphne gnidium } \\
\hline Erica arborea & $\mathrm{x}$ & \\
\hline Erica australis & $x$ & $x$ \\
\hline Erica lusitanica & $x$ & \\
\hline Erica scoparia & $x$ & \\
\hline Erica umbellata & $x$ & \\
\hline Genista falcata & $x$ & $x$ \\
\hline \multicolumn{3}{|l|}{ Halimium lasianthum } \\
\hline \multicolumn{3}{|l|}{ Ilex aquifolium } \\
\hline \multicolumn{3}{|l|}{ Lavandula luisieri } \\
\hline \multicolumn{3}{|l|}{ Lithodora prustrata } \\
\hline \multicolumn{3}{|l|}{ Phillyrea angustifolia } \\
\hline \multicolumn{3}{|l|}{ Prunus lusitanica } \\
\hline Pterospartum tridentatum & $\mathrm{x}$ & \\
\hline \multicolumn{3}{|l|}{ Rhamnus alaternus } \\
\hline Rubus ulmifolius & $x$ & \\
\hline \multicolumn{3}{|l|}{ Ruscus aculeatus } \\
\hline Ulex minor & $x$ & \\
\hline Viburnum tinus & & \\
\hline
\end{tabular}

Of the 28 shrub and small tree species identified in the region, 16 are heliophilous, namely, Adenocarpus cumplicatus, Calluna vulgaris, Cistus populifolius, Cistus psilosepalus, Cistus salviifolius, Cytisus multiflorus, Cytisus striatus, Erica arborea, Erica australis, Erica lusitanica, Erica umbellata, Genista falcata, Pterospartum tridentatum, Rubus ulmifolius and Ulex minor. Of these 16 species, 7 are considered dominant, representing the largest occupied area, namely, Calluna vulgaris, Cistus psilosepalus, Cistus salviifolius, Cytisus multiflorus, Cytisus striatus, Erica australis and Genista falcata.

Approximately $1 \mathrm{~kg}$ of each species was collected, only from the aboveground parts, so that whenever the specimen was pulled out, the part corresponding to the root was cut. From the aboveground parts, stem, branches and leaves were collected, which were subsequently dried in a laboratory greenhouse and crushed to carry out the physical-chemical characterization tests. In Figure 2, some examples of the samples collected are shown. 


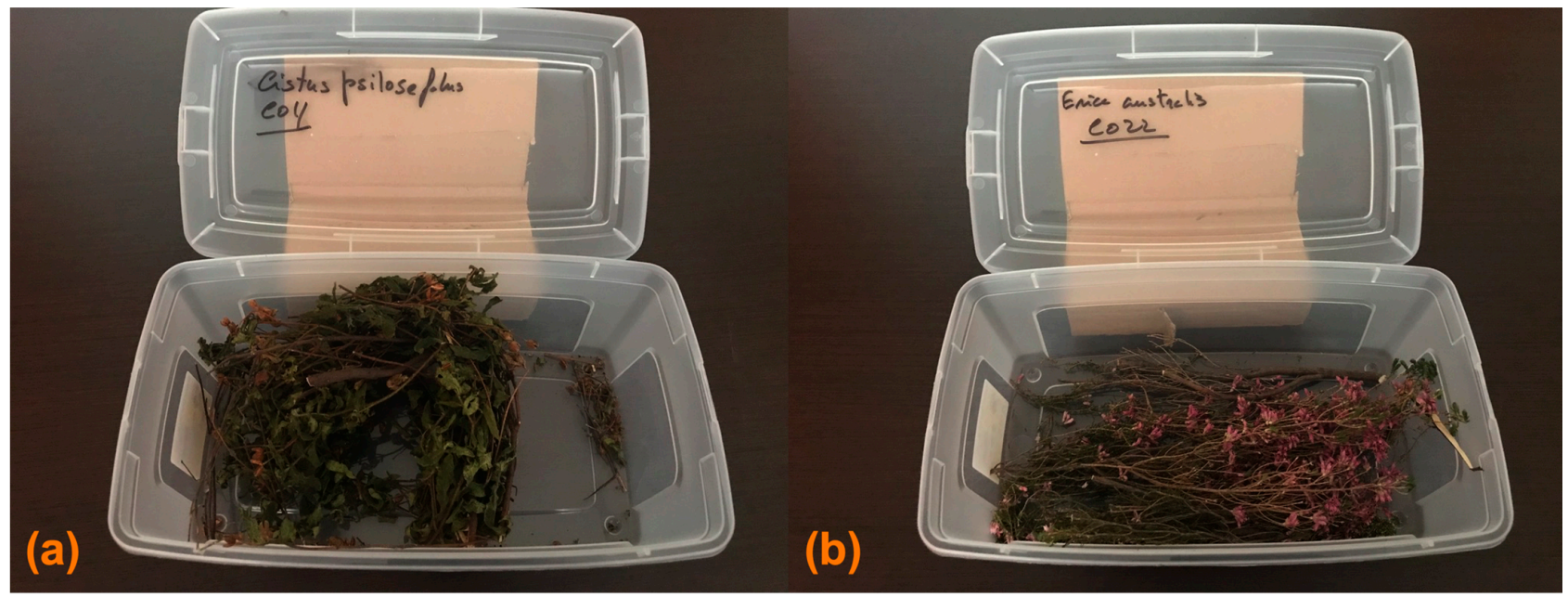

Figure 2. Examples of the samples collected. (a) Sample of Cistus psilosepalus and (b) sample of Erica australis.

\subsection{Laboratory Characterization Tests}

To carry out the laboratory characterization tests, the procedures described in the reference standards that support the ENplus ${ }^{\circledR}$ standard were used, since this normative system allows for an easier comparison with the species that are usually used in the production of bioenergy. Thus, laboratory characterization tests were performed using the following standards:

- ISO 17225-1: 2014—Solid biofuels-Fuel specifications and classes—Part 1: General requirements;

- ISO 16948: 2015—Solid biofuels—Determination of total content of carbon, hydrogen and nitrogen;

- ISO 16967: 2015-Solid biofuels—Determination of major elements- $\mathrm{Al}, \mathrm{Ca}, \mathrm{Fe}, \mathrm{Mg}, \mathrm{P}$, $\mathrm{K}, \mathrm{Si}, \mathrm{Na}$ and $\mathrm{Ti}$;

- ISO 16968: 2015-Solid biofuels-Determination of minor elements-Ar, Cd, Cobalt, $\mathrm{Cr}$, Copper, $\mathrm{Hg}, \mathrm{Mn}, \mathrm{Mo}, \mathrm{Ni}, \mathrm{Pb}, \mathrm{Sb}, \mathrm{V}$ and $\mathrm{Zn}$;

- ISO 16994: 2016-Solid biofuels-Determination of total content of sulfur and chlorine;

- ISO 18125: 2017-Solid biofuels-Determination of calorific value;

- ISO 21404: 2020(en)—Solid biofuels—Determination of ash melting behavior.

\section{Results and Discussion}

\subsection{Thermogravimetric Analysis (TGA)}

The results obtained in the thermogravimetric analysis are shown in Figure 3.

Thermogravimetric analysis is of great importance as it allows one to understand the behavior of different materials during the thermal degradation process. Thus, from the parameters normally analyzed in thermogravimetry, especially when the materials are used for energy recovery, ash appears to be a determining factor, since an excessive amount of ash can greatly affect the use of the material as a fuel. Several works have focused on the production and characterization of ash resulting from the combustion of biomass, whether resulting from residual biomass or from biomass-derived fuels such as wood pellets. Exploratory works involving the characterization of the biomass types analyzed in the present work have been presented from the perspective of energy recovery, such as the work presented by Marques et al. (2011), where the possibility of pellet production from species belonging to the genera Cytisus and Cistus is analyzed [30], or the work presented by Marques et al. (2019), where the characterization of charcoals produced with blends of Cytisus with cork residues, Cistus with Eucalyptus and Cytisus with Cistus is presented [31]. The results obtained in this study show a very wide dispersion, and following the results obtained in previous works, the species Cytisus striatus has the lowest ash value of $1.32 \%$, 
followed by a set of 7 more species, namely, Pterospartum tridentatum, Erica australis, Genista falcata, Erica lusitanica, Cytisus multiflorus, Erica arborea and Cistus psilosepalus, with values between $1.37 \%$ and $1.94 \%$. These values still fall within the limits imposed by ENplus ${ }^{\circledR}$ for Category B pellets but are not applicable to Category A1 or A2 pellets, which have a maximum limit of $0.7 \%$ and $1.2 \%$, respectively. The remaining species studied show even higher values, ranging from $2.08 \%$ for Ulex minor to $5.52 \%$ for Lithodora prustrata.

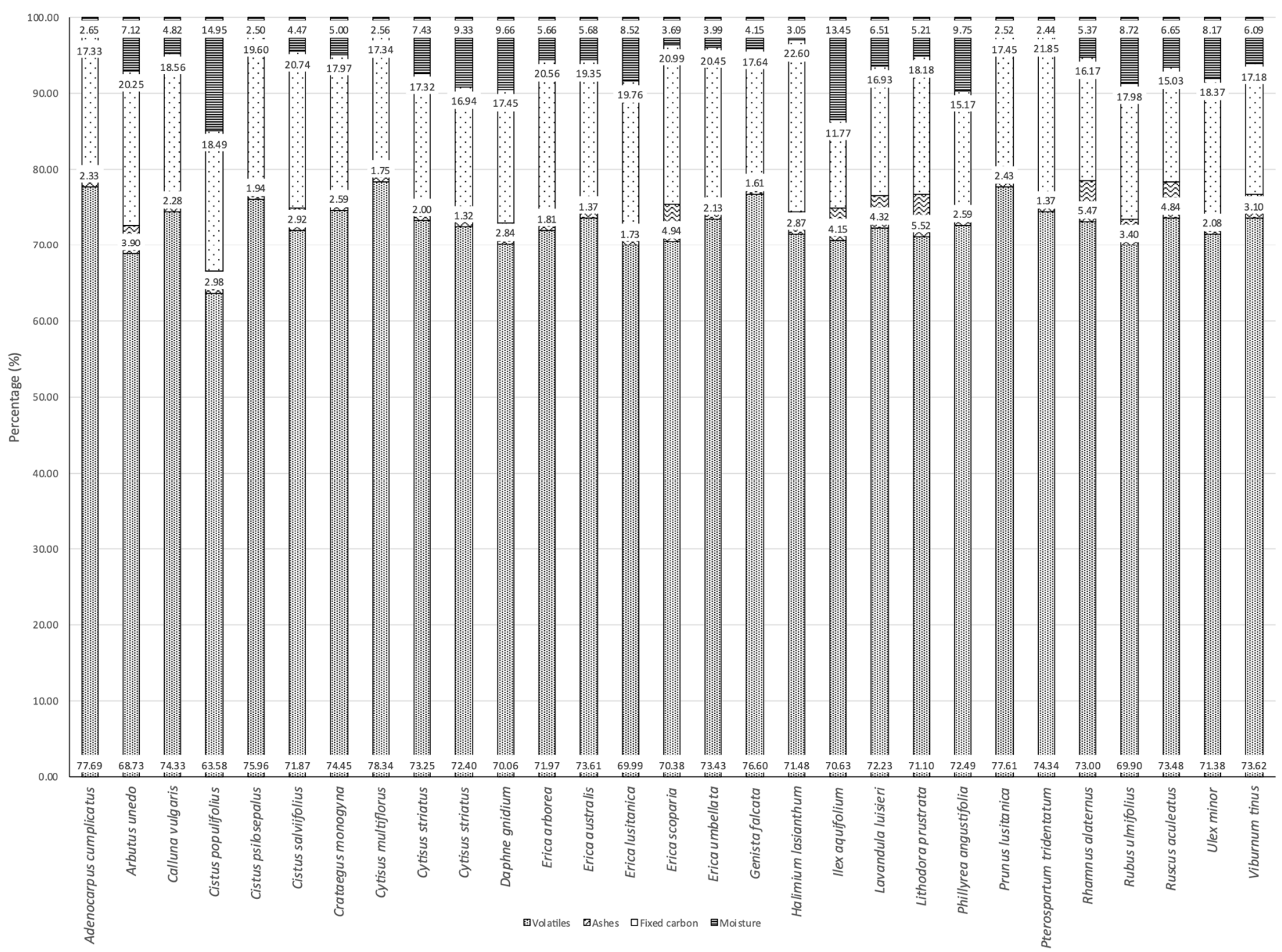

Figure 3. Results of the thermogravimetric analysis (TGA). The results are presented for the contents of ash, volatiles and fixed carbon.

The volatile content is another parameter that has a direct impact on how these materials behave during combustion, and this perspective can be analyzed not only for the moment of energy recovery, but also to analyze the perspective of the behavior of these species in rural fires. This relationship is even more important if analyzed in line with another parameter, which is the fixed carbon content. Of all studied species, the one with the lowest volatile content was Cistus populifolius, with $63.58 \%$, followed by a group of species with a variation of less than $10 \%$ in relation to this and that are dominant species, such as Cistus salviifolius or Cytisus striatus with $72.40 \%$ and $71.87 \%$, respectively. The species that presented a difference higher than $10 \%$ included a wide group of dominant species, such as Calluna vulgaris with $74.33 \%$, Genista falcata with $76.60 \%$ and Cytisus multiflorus with $78.34 \%$, which also presents the highest value found in this group of species. The species that presented the lowest fixed carbon content was Ilex aquifolium, with $11.77 \%$, followed by a group of 25 species with a variation lower than $10 \%$ in relation to this species and 
where there are dominant species such as Cytisus striatus, Genista falcata and Erica australis, with $16.94 \%, 17.64 \%$ and $19.35 \%$, respectively. Species with a difference greater than $10 \%$ included Pterospartum tridentatum, with $21.85 \%$, and Halimium lasianthum, with $22.60 \%$. The relationship established between the volatile content and the fixed carbon content is related to the capacity of the fuels to burn more intensely due to the quantity of volatiles that are released from the solid mass during the pyrolysis phase of combustion. This characteristic is important to understand the behavior of materials during combustion, whether from the perspective of energy recovery or the behavior during rural fires. Thus, the higher the ratio between the volatile content and the fixed carbon content is, the more intense and faster the combustion will be, and vice versa. This relationship allows, for example, to determine the speed of propagation of a rural fire, based only on the combustibility of the materials. Figure 4 shows the relationship between the volatile content and the fixed carbon content.

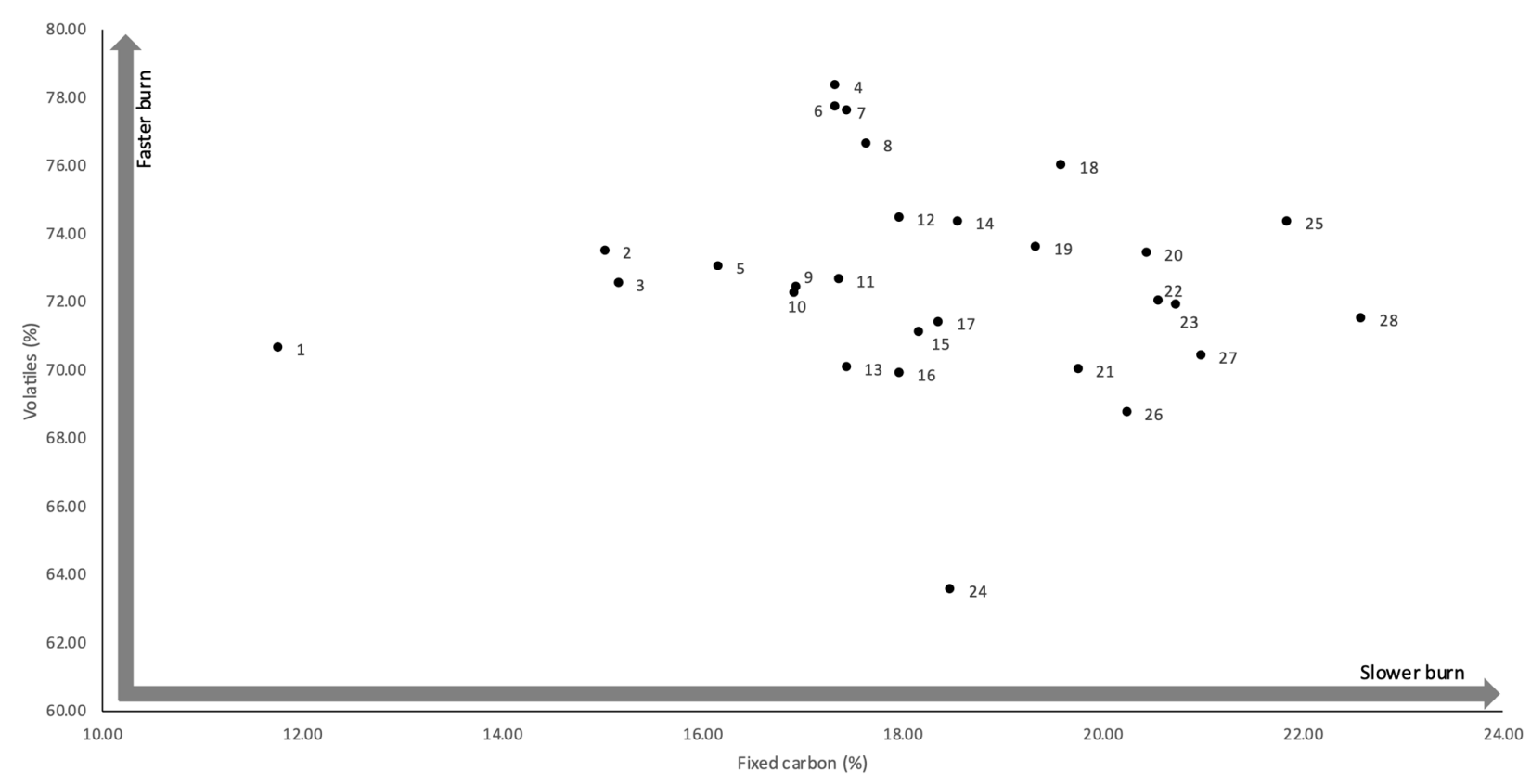

Figure 4. Projection of volatile and fixed carbon contents and their relationship to combustion speed. Legend: 1 -Ilex aquifolium; 2-Ruscus aculeatus; 3-Phillyrea angustifolia; 4-Cytisus multiflorus; 5-Rhamnus alaternus; 6-Adenocarpus cumplicatus; 7-Prunus lusitanica; 8-Genista falcata; 9-Cytisus striatus; 10—Lavandula luisieri; 11-Viburnum tinus; 12Crataegus monogyna; 13-Daphne gnidium; 14-Calluna vulgaris; 15-Lithodora prustrata; 16-Rubus ulmifolius; 17-Ulex minor; 18-Cistus psilosepalus; 19-Erica australis; 20_Erica umbellata; 21-Erica lusitanica; 22-Erica arborea; 23-Cistus salviifolius; 24-Cistus populifolius; 25-Pterospartum tridentatum; 26-Arbutus unedo; 27-Erica scoparia; 28-Halimium lasianthum.

As can be seen, Species 20, 21, 22, 23, 24, 25, 26, 27 and 28 show a tendency towards slower combustion, while Species 1, 2, 3, 4, 5, 6, 7 and 8 show a tendency towards more intense and faster combustion. Of these, Species 23 (Cistus salviifolius) may be of particular concern, as it is both a heliophile and dominant in the stands where it appears, and may be a species that can prolong its combustion for long periods of time due to its high content of fixed carbon, while Species 4 (Cytisus multiflorus) and 8 (Genista falcata) have high levels of volatiles and are also heliophilous and dominant in their stands, with intense and accelerated combustibility. These species are potentially dangerous as they can burn very quickly in rural fires, allowing for fire dispersal. From the opposite perspective, species such as Cistus salviifolius with a slower combustibility due to the lower volatile content may be associated with rekindling. This analysis of combustibility is in accordance with the work presented by Shan et al. (2018), who concluded that the ratio between the estimated char burnout time and volatile combustion time increases quadratically with the fixed carbon to volatile matter mass ratio, confirming that char combustion is much slower than volatile combustion [32]. This relationship is quite evident if the FC/V ratios are 
projected as a function of $\mathrm{V} / \mathrm{FC}$, which has a distribution indicating which species have a more intense and faster combustion and which species have a slower and less intense combustibility. Figure 5 shows the projection of the FC/V and V/FC ratios.

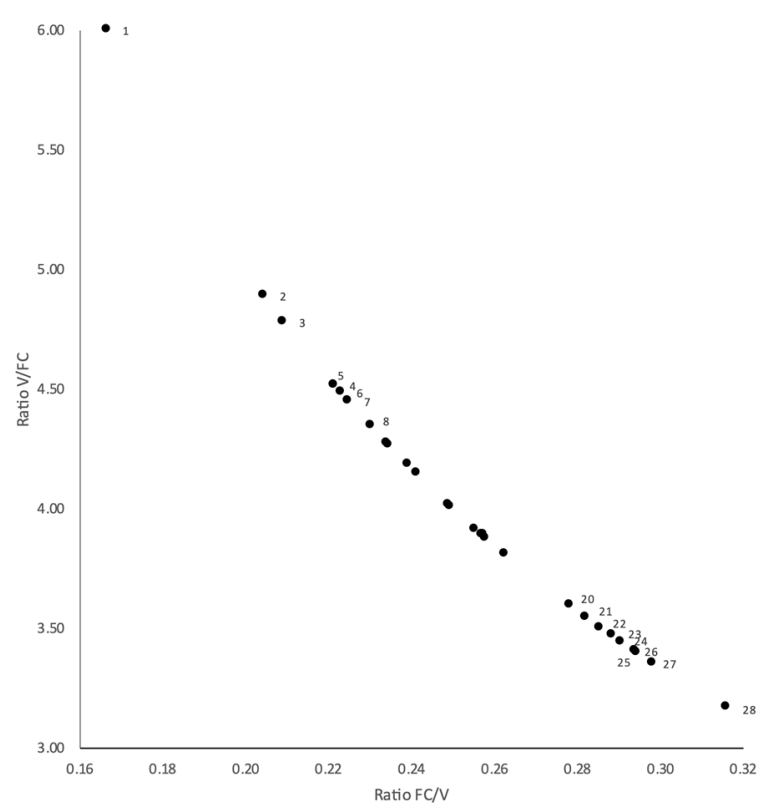

Figure 5. Projection of the FC/V and V/FC ratios. Legend: 1-Ilex aquifolium; 2-Ruscus aculeatus; 3-Phillyrea angustifolia; 4-Cytisus multiflorus; 5-Rhamnus alaternus; 6-Adenocarpus cumplicatus; 7-Prunus lusitanica; 8-Genista falcata; 9-Cytisus striatus; 10-Lavandula luisieri; 11-Viburnum tinus; 12-Crataegus monogyna; 13-Daphne gnidium; 14-Calluna vulgaris; 15-Lithodora prustrata; 16-Rubus ulmifolius; 17-Ulex minor; 18-Cistus psilosepalus; 19-Erica australis; 20_Erica umbellata; 21-Erica lusitanica; 22-Erica arborea; 23-Cistus salviifolius; 24-Cistus populifolius; 25-Pterospartum tridentatum; 26-Arbutus unedo; 27-Erica scoparia; 28-Halimium lasianthum.

\subsection{Elemental Analysis (CHNO)}

The results obtained in the elemental analysis are shown in Figure 6 for the carbon content, in Figure 7 for the hydrogen content and in Figure 8 for the oxygen content.

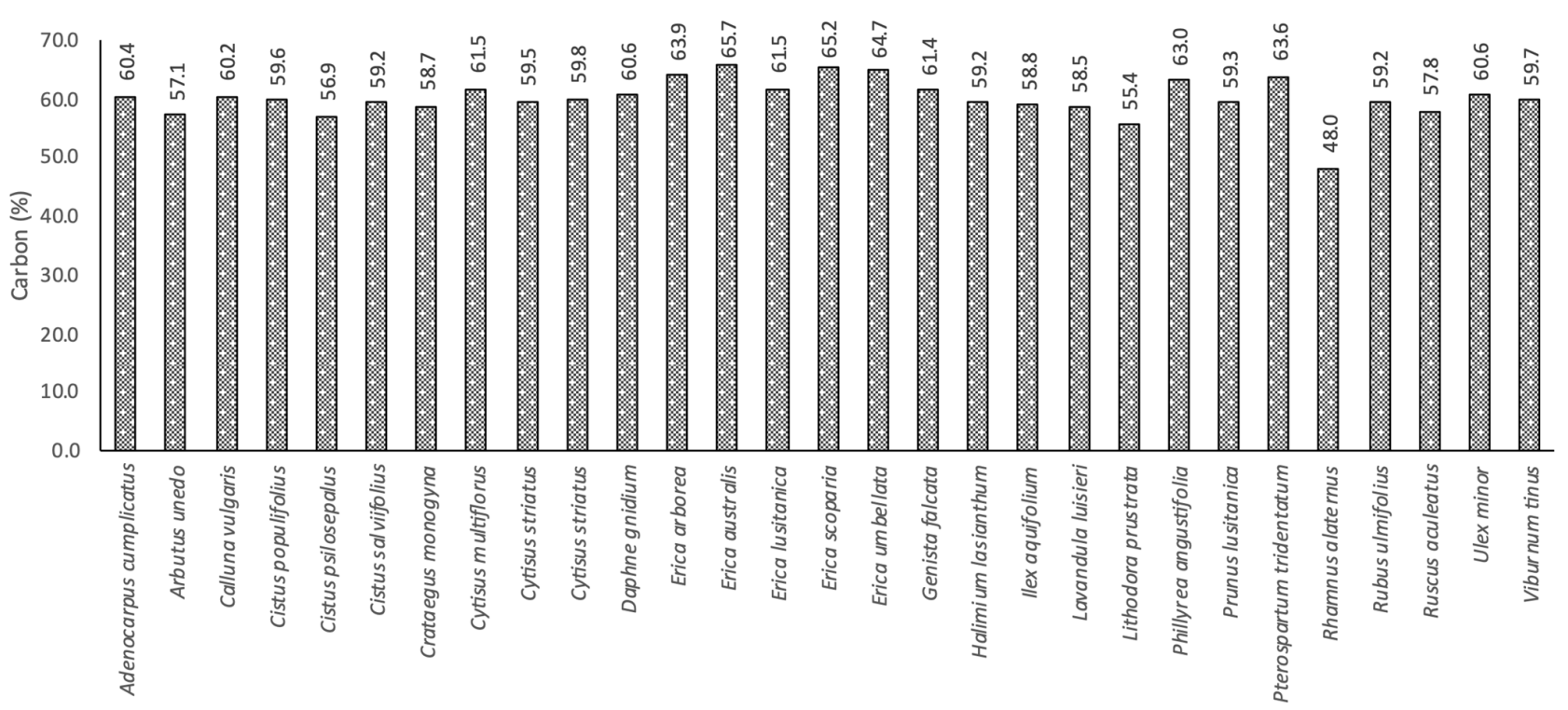

Figure 6. Carbon content (\%) of the studied species. 


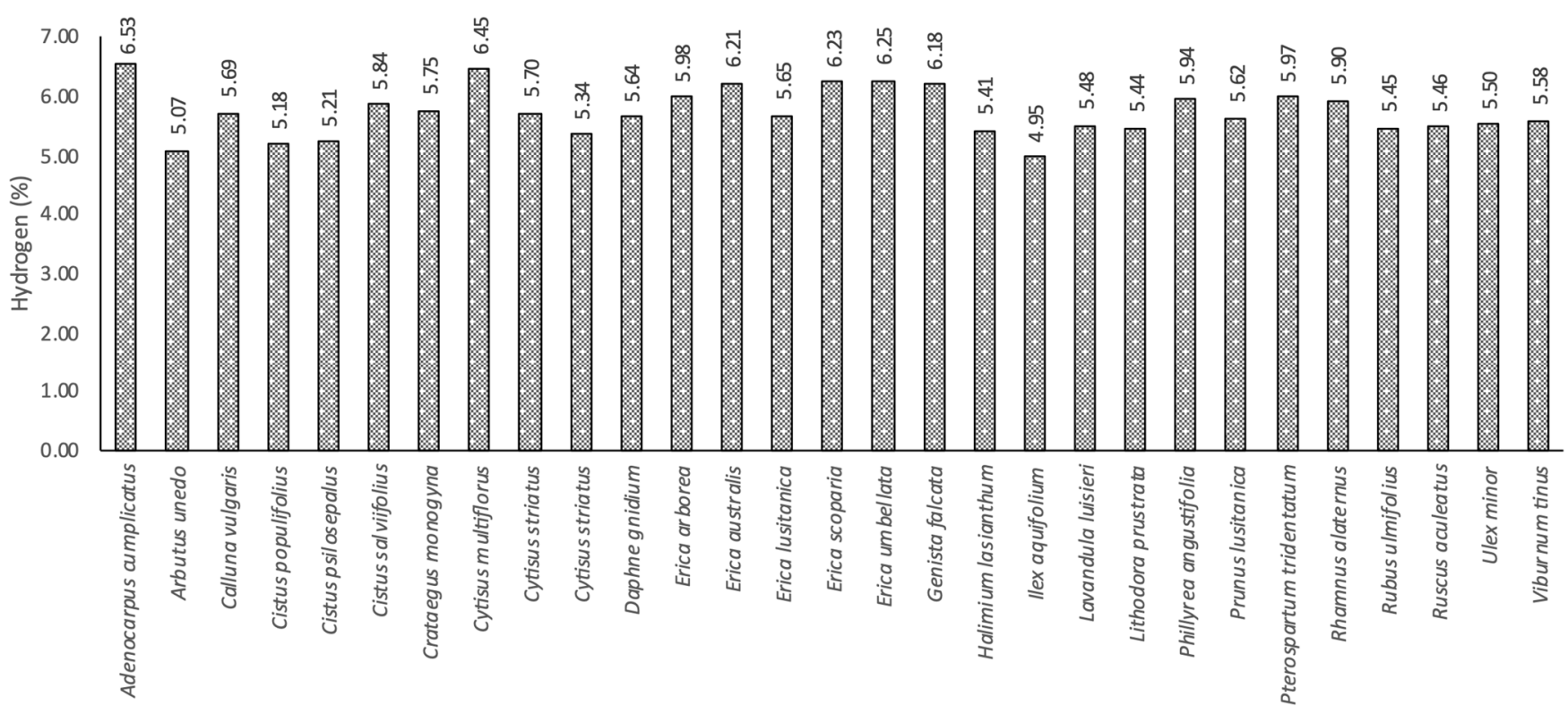

Figure 7. Hydrogen content (\%) of the studied species.

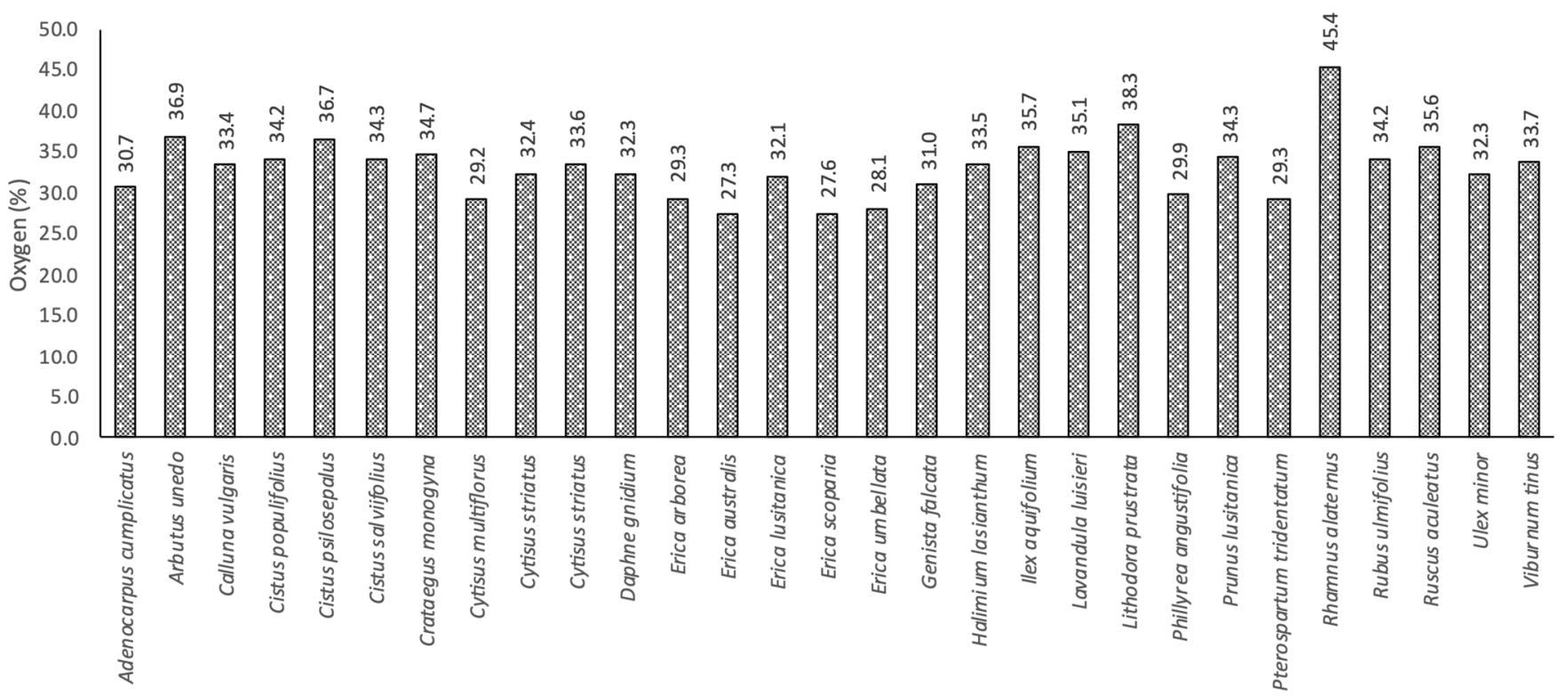

Figure 8. Oxygen content (\%) of the studied species.

The carbon content of the species studied varied between the minimum value of $48.0 \%$, in Rhamnus alaternus, and the maximum value of $65.7 \%$, in Erica australis. The remaining species had an average value of $59.97 \%$. The hydrogen content of the studied species varied between a minimum of $4.95 \%$, in Ilex aquifolium, and a maximum value of $6.53 \%$, in Adenocarpus cumplicatus. The remaining species had an average value of $5.71 \%$. The oxygen content of the studied species varied between the minimum value of $27.3 \%$, in Erica australis, and the maximum value of $45.4 \%$, in Rhamnus alaternus. The remaining species had an average value of $33.13 \%$. These distributions allow one, in a first analysis, to consider that they have a high carbon content; therefore, from the point of view of their combustibility, as previously analyzed, their potential as a fuel is high. The high levels of hydrogen also point in this direction. Additionally, regarding the oxygen content, the low values presented indicate reduced combustibility, since the higher the number and concentration levels of oxygen compounds are, the lower the energy density will be. 
These species present, on average, higher values than those found in species such as Pinus pinaster and Eucalyptus globulus, commonly used in the production of fuels derived from biomass, such as wood pellets. Nunes et al. (2021) presented values for the levels of carbon, hydrogen and oxygen of these two species, with $50.2 \%, 6.07 \%$ and $43.6 \%$ for Pinus pinaster and $47.9 \%, 5.67 \%$ and $46.9 \%$ for Eucalyptus globulus, respectively, demonstrating that some of these species have even better potential characteristics to have higher calorific powers due to the higher levels of carbon and hydrogen, while at the same time, they present lower levels of oxygen [33]. This situation can be shown with the projection of the $\mathrm{H} / \mathrm{C}$ and $\mathrm{O} / \mathrm{C}$ ratios on a graph by van Krevelen, as presented in Figure 9. In the figure, all species apart from Rhamnus alaternus show a position closer to the origin of the graph relative to the position of the projection of Pinus pinaster and Eucalyptus globulus, indicating a higher heating value.

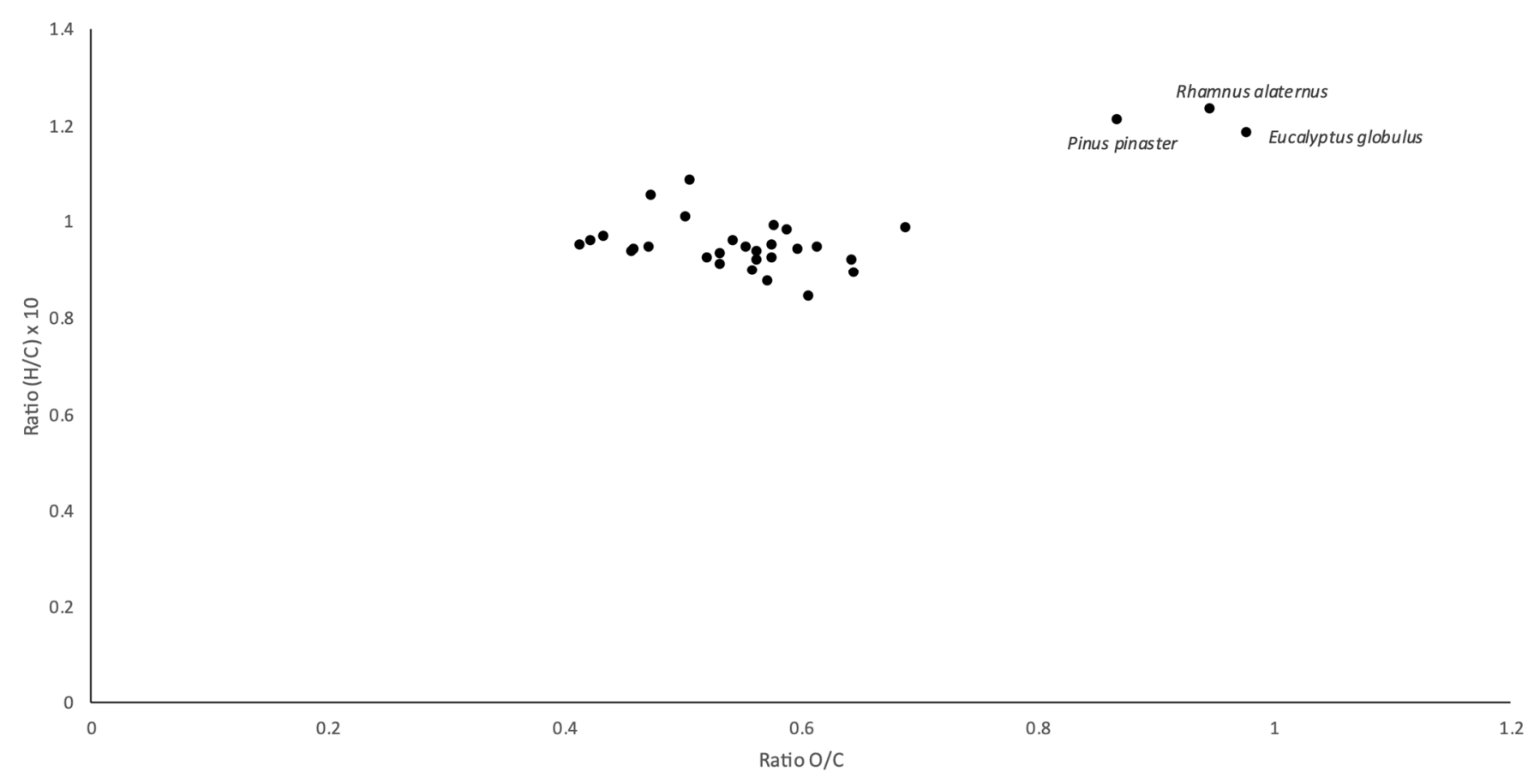

Figure 9. Van Krevelen diagram.

The results obtained in the elemental analysis for the nitrogen content are presented in Figure 10.

The nitrogen content of the studied species varied between the minimum value of $0.528 \%$, in Ilex aquifolium, and the maximum value of $2.87 \%$, in Cytisus multiflorus. The remaining species had an average value of $1.19 \%$. These values are much higher than those presented by Nunes et al. (2021) for species normally used in the production of wood pellets, such as Pinus pinaster and Eucalyptus globulus, which have nitrogen contents of $0.077 \%$ and $0.099 \%$, respectively [33]. In this way, the combustion of these species, whether in terms of energy recovery or in the event of rural fires, will be responsible for the emission of $\mathrm{NO}_{\mathrm{x}}$. This $\mathrm{NO}_{\mathrm{x}}$ formation occurs when the nitrogen and oxygen levels in fuel are high and can be minimized by acting directly in the process, with the alteration of the burning parameters in the case of energy recovery, namely, in terms of air intake, dissipation of thermal power or even the recirculation of combustion gases. 


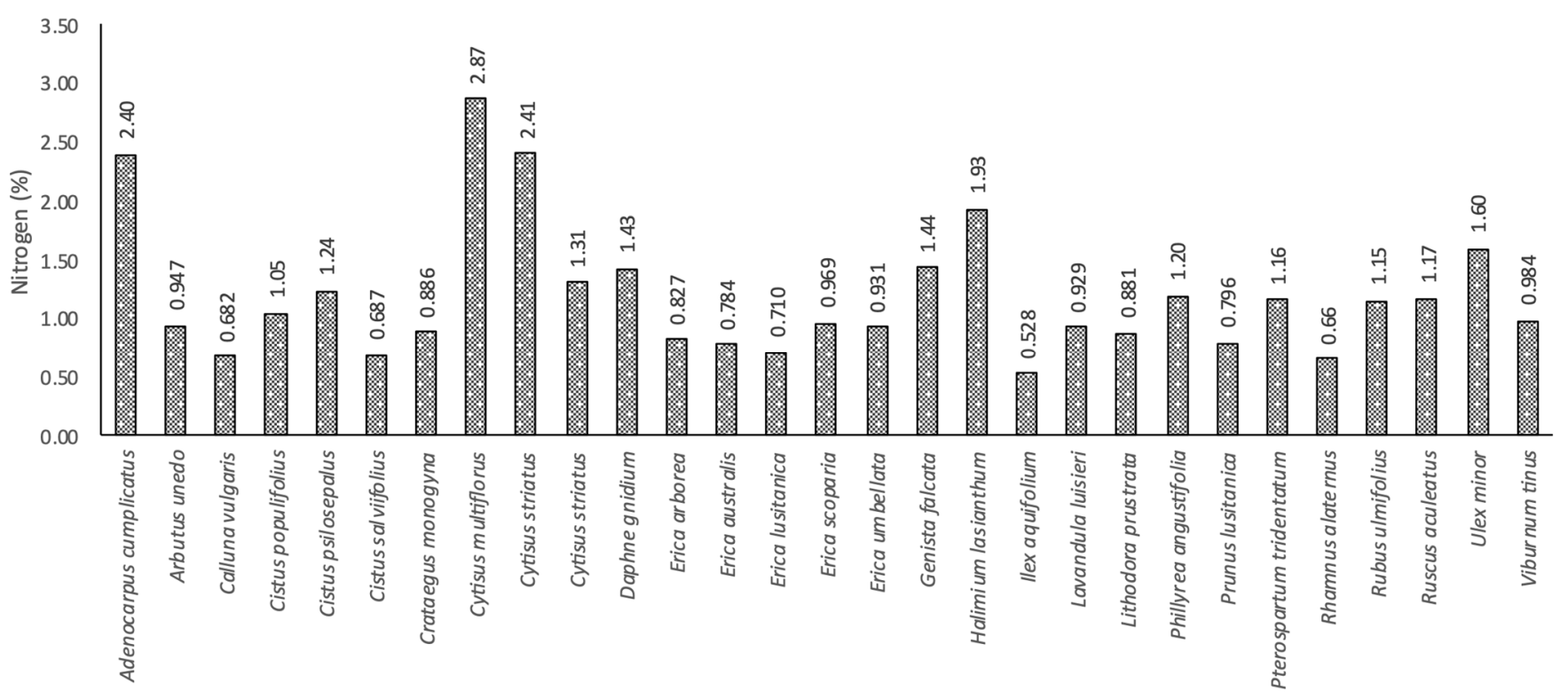

Figure 10. Nitrogen content (\%) of the studied species.

\subsection{Heating Value (HHV and LHV)}

The results obtained in the laboratory for the heating value are presented in Figure 11. As can be seen from the obtained results, the lowest value for HHV and for LHV was 17.52 and $16.29 \mathrm{MJ} / \mathrm{kg}$, respectively, for Daphne gnidium, while the highest value was 22.98 and $21.64 \mathrm{MJ} / \mathrm{kg}$, respectively, for Erica scoparia. The average value presented by the other species was $20.53 \mathrm{MJ} / \mathrm{kg}$ for HHV and $19.29 \mathrm{MJ} / \mathrm{kg}$ for LHV. Comparing the values presented by the species under study with the species most used in the production of, for example, wood pellets, which present values of 19.35 and $17.87 \mathrm{MJ} / \mathrm{kg}$ for Pinus pinaster and of 19.35 and $18.15 \mathrm{MJ} / \mathrm{kg}$ for Eucalyptus globulus, respectively [33], it appears that the values obtained have a high potential for energy recovery with regard to this parameter.

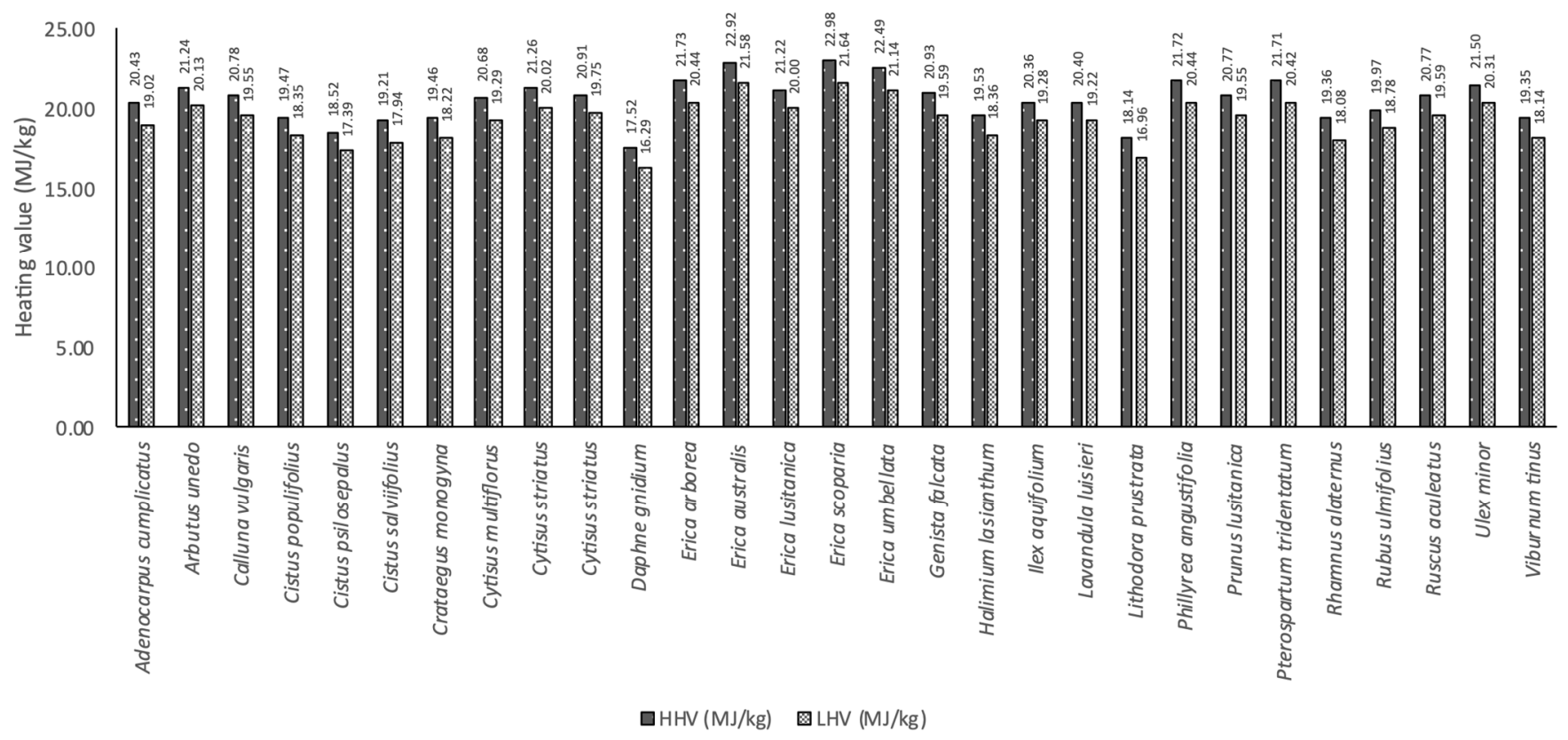

Figure 11. High heating value (HHV) and low heating value (LHV). 


\subsection{Chlorine and Sulfur Contents}

The results obtained for the levels of chlorine and sulfur are presented in Figure 12.

口Chlorine (d) 圆Sulphur (S)

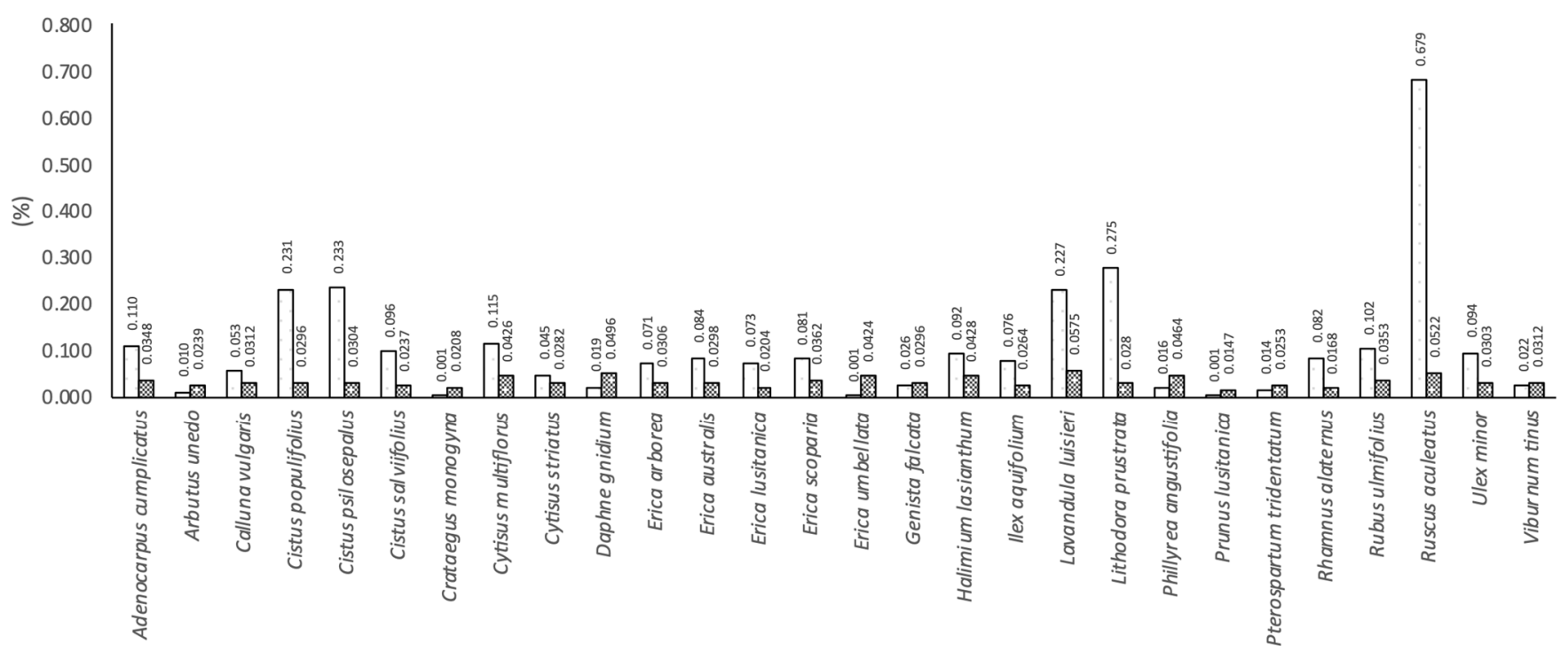

Figure 12. Chlorine and sulfur contents.

The chlorine levels indicated a tendency toward high values. Chlorine is a very mobile element, which has the function of regulating osmosis and ion compensation. That is, chlorine regulates the movement of cations, atoms and small molecules inside and outside plant cells, which constitute normal cellular activity. Although the need for chlorine is usually small to maintain adequate plant growth, its concentrations can be high, often reaching the concentrations found in macro-nutrients. The results obtained show that only the non-heliophilous and non-dominant species, such as Arbutus unedo, Crataegus monogyna, Daphne gnidium, Phillyrea angustifolia and Prunus lusitanica, presented values below $0.02 \%$. This value is the limit shown in the ENplus ${ }^{\circledR}$ standard. In the case of biomass normally used to produce wood pellets, only Pinus pinaster presented values below $0.02 \%$, while Eucalyptus globulus presented higher values, normally close to $0.04 \%$. In the results obtained, in addition to the non-heliophilous and non-dominant species, Erica umbellata and Pterispartum tridentatum also presented low chlorine values below $0.02 \%$. However, although these species are heliophilous, they are not dominant, so they are not expected to have large stands, nor to cover large areas. The remaining analyzed species presented values varying from $0.022 \%$, which is slightly above the limit value of the ENplus ${ }^{\circledR}$ standard, as was the case with Viburnum tinus, up to $0.679 \%$, as in Ruscus aculeatus, which even differs greatly in the order of magnitude of the remaining results, where the values were in the range between $0.026 \%$ and $0.275 \%$. It should be noted that, as expected, dominant heliophilous species, such as Calluna vulgaris, Cistus psilosepalus, Cistus salviifolius, Cytisus multiflorus, Cytisus striatus, Erica australis or Genista falcata, have high chlorine values compared to the limit values of the ENplus ${ }^{\circledR}$ standard but also to the other species, so this presence of chlorine is surely associated with the ability to develop rapidly, which is naturally occurring in heliophilous and dominant species.

In terms of sulfur content, the limit values presented in the ENplus ${ }^{\circledR}$ standard are $0.04 \%$ and $0.05 \%$ for wood pellets of categories A1 and A2 and for wood pellets of Category B, respectively. Only the species Daphne gnidium, Lavandula luisieri, Phillyrea angustifolia and Ruscus aculeatus presented values equal to or greater than the limit imposed by the standard ENplus ${ }^{\circledR}$ for Category B. However, the values obtained in all species are relatively high compared to those found in tree species, such as Pinus pinaster, which had an average value of $0.005 \%$. These results are in agreement with the fact that sulfur is one of the 
constituents of amino acids and proteins, being closely linked to leguminous species, but also participates in the synthesis of chlorophyll and $\mathrm{CO}_{2}$ absorption [34]. For this reason, it is expected to be present in herbaceous and shrub species in greater quantities than in tree species, and in the case of dominant heliophilous species, this content is even higher given the rapid growth capacity that these species present.

\subsection{Chemical Analysis by ICP-OES}

\subsubsection{Major Elements and Ash Fusibility}

The results obtained for the larger elements $\mathrm{Ca}, \mathrm{Na}$ and $\mathrm{K}$ in the chemical analysis by ICP-OES are shown in Figure 13. The same figure also shows the results obtained for the ash fusibility temperature, specifically for the softening temperature.

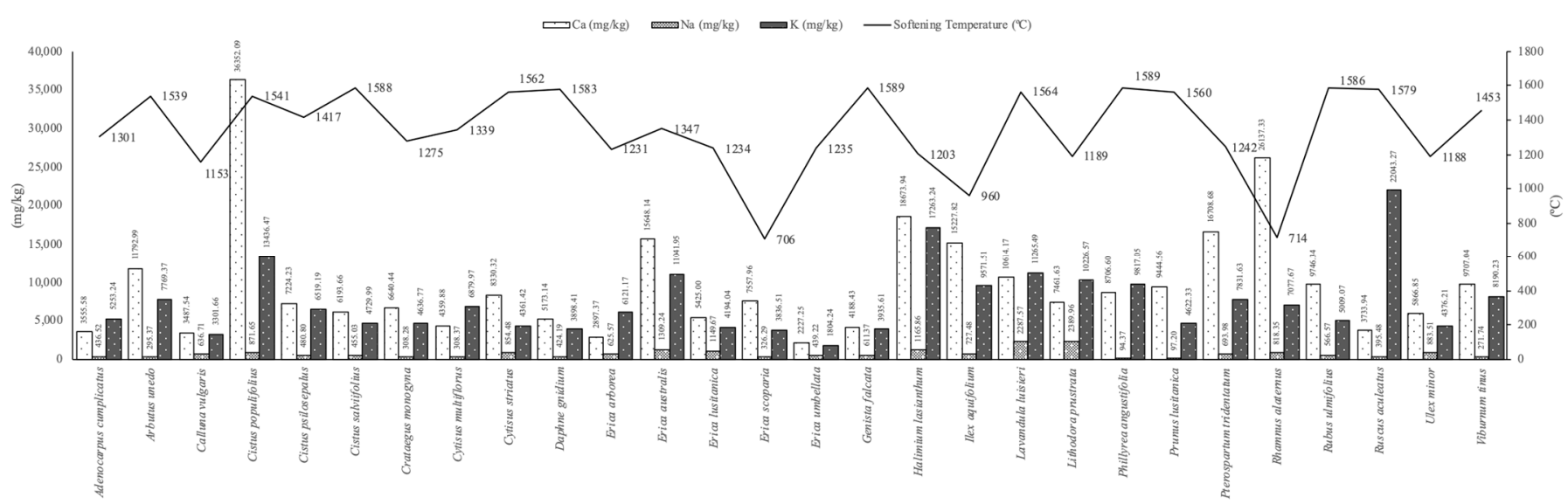

Figure 13. Content of $\mathrm{Ca}, \mathrm{Na}$ and $\mathrm{K}(\mathrm{mg} / \mathrm{kg})$ and softening temperature $\left({ }^{\circ} \mathrm{C}\right)$.

As can be seen in Figure 13, the species that present deformation temperatures below $1200{ }^{\circ} \mathrm{C}$, which is the lower limit indicated by the ENplus ${ }^{\circledR}$ standard, are also those that have higher levels of $\mathrm{Ca}, \mathrm{Na}$ and $\mathrm{K}$. The relationship between the content of $\mathrm{Ca}$ and the contents of $\mathrm{Na}$ and $\mathrm{K}$ increases the probability of occurrence of fouling and slagging phenomena, as presented by Rodrigues et al. (2020) [35]. Ca, when acting as a fluidizing agent, causes the softening temperature to drop-significantly in some situations-as observed for the case of Erica scoparia, Ilex aquifolium and Rhamnus alaternus, where the 2:1 ratio of $\mathrm{Ca}$ and of $\mathrm{K}$ and a ratio greater than 8:1 of $\mathrm{Ca}$ and $\mathrm{Na}$ clearly enhance the reduction in the deformation temperature. The occurrence of fouling and slagging phenomena will be even more intense with the occurrence of high levels of both $\mathrm{Si}$ and $\mathrm{Al}$.

Figure 14 shows the conjugated levels of $\mathrm{Si}$ and $\mathrm{Al}$ for the samples under study.

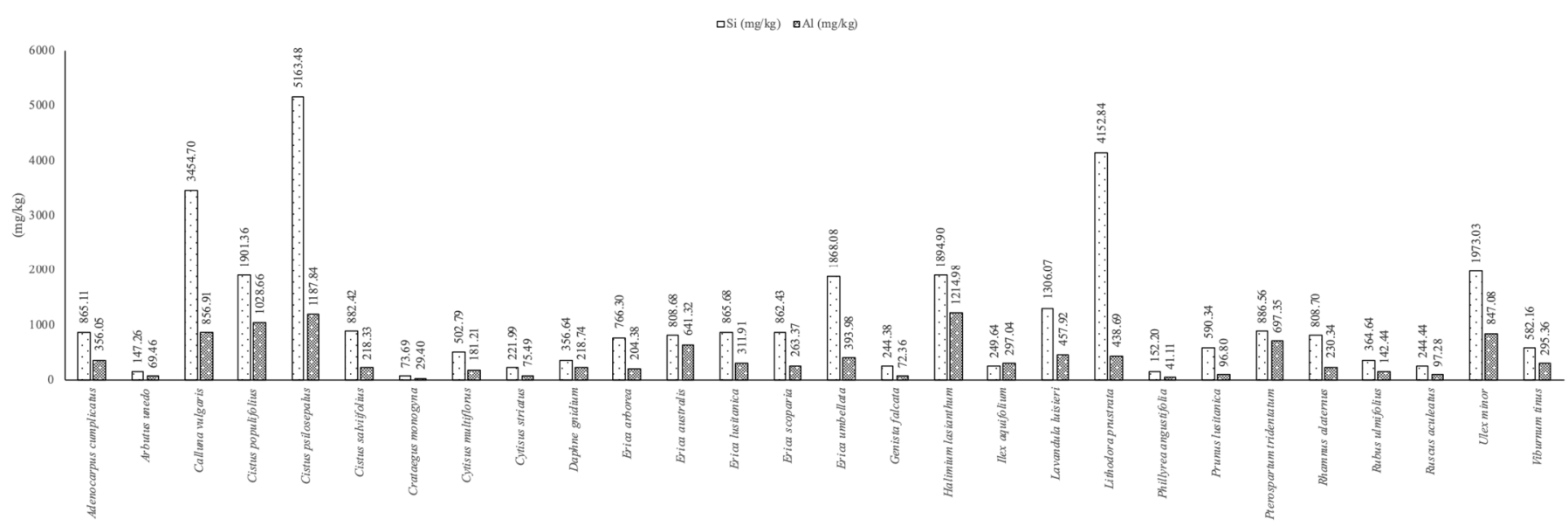

Figure 14. $\mathrm{Si}$ and $\mathrm{Al}$ contents $(\mathrm{mg} / \mathrm{kg})$. 
As can be seen, for the cases where the highest levels of $\mathrm{Ca}$, $\mathrm{Na}$ and $\mathrm{K}$ were found and which presented, simultaneously, the lowest deformation temperatures, the levels of $\mathrm{Si}$ and $\mathrm{Al}$ do not correspond. However, for the species Calluna vulgaris, Lithodora prustrata and Ulex minor, although they present deformation temperatures higher than those of the other species previously mentioned, they also present deformation temperatures below $1200{ }^{\circ} \mathrm{C}$ with the aggravation of also presenting high $\mathrm{Si}$ and $\mathrm{Al}$ contents. In these cases, the probability of occurrence of vitrification and ash sintering phenomena is very high.

\subsubsection{Minor Elements}

The results obtained for the determination of the minor elements by ICP-OES are shown in Table 2.

Table 2. Minor elements ( $\mathrm{mg} / \mathrm{kg})$.

\begin{tabular}{|c|c|c|c|c|c|c|c|c|c|}
\hline Species & As & $\mathrm{Cd}$ & Co & $\mathrm{Cr}$ & $\mathrm{Cu}$ & Mn & $\mathrm{Ni}$ & $\mathbf{P b}$ & $\mathrm{Zn}$ \\
\hline Adenocarpus cumplicatus & 3.88 & 0 & 0 & 1.14 & 6.26 & 259.22 & 0.15 & 0 & 24.95 \\
\hline Arbutus unedo & 3.65 & 0 & 0 & 0 & 3.65 & 25.17 & 0 & 0 & 41.02 \\
\hline Calluna vulgaris & 4.71 & 0 & 0 & 3.71 & 5.58 & 364.92 & 1.83 & 0 & 13.72 \\
\hline Cistus populifolius & 4.65 & 1.00 & 6.66 & 4.78 & 16.61 & 2124.02 & 5.69 & 2.85 & 104.84 \\
\hline Cistus psilosepalus & 5.66 & 0 & 0.93 & 2.08 & 12.01 & 210.49 & 0.05 & 0 & 79.30 \\
\hline Cistus salviifolius & 3.53 & 0 & 0 & 0.77 & 5.52 & 214.89 & 0.15 & 2.12 & 41.06 \\
\hline Crataegus monogyna & 1.53 & 0.03 & 0 & 0.14 & 7.33 & 16.66 & 0.60 & 0.76 & 25.85 \\
\hline Cytisus multiflorus & 2.07 & 0 & 0.47 & 0.57 & 17.30 & 479.08 & 3.89 & 1.28 & 72.55 \\
\hline Cytisus striatus & 3.79 & 0.06 & 0.05 & 0.77 & 6.24 & 446.43 & 0.43 & 0 & 34.09 \\
\hline Daphne gnidium & 2.91 & 0 & 1.84 & 1.83 & 12.01 & 219.31 & 2.36 & 0 & 71.83 \\
\hline Erica arborea & 3.05 & 0 & 0 & 0.45 & 5.52 & 588.13 & 0 & 0 & 23.94 \\
\hline Erica australis & 4.72 & 0.01 & 0.67 & 1.54 & 11.63 & 826.35 & 3.29 & 1.96 & 19.13 \\
\hline Erica lusitanica & 3.07 & 0 & 0.12 & 1.25 & 4.62 & 562.67 & 1.09 & 0 & 11.31 \\
\hline Erica scoparia & 4.70 & 0.05 & 0.26 & 0.53 & 5.89 & 86.28 & 1.08 & 0 & 15.95 \\
\hline Erica umbellata & 4.75 & 0 & 0.08 & 1.81 & 4.22 & 149.95 & 1.31 & 1.83 & 21.96 \\
\hline Genista falcata & 2.23 & 1.29 & 1.55 & 0.34 & 5.33 & 87.70 & 2.91 & 2.28 & 22.78 \\
\hline Halimium lasianthum & 4.19 & 0.69 & 7.21 & 1.93 & 20.83 & 613.73 & 7.76 & 3.63 & 89.07 \\
\hline Ilex aquifolium & 4.85 & 0.78 & 0.82 & 1.06 & 3.06 & 823.12 & 0.63 & 0.46 & 144.36 \\
\hline Lavandula luisieri & 3.99 & 0.14 & 0.37 & 1.48 & 6.93 & 335.85 & 1.49 & 0 & 56.85 \\
\hline Lithodora prustrata & 4.52 & 0 & 0 & 0.13 & 5.23 & 96.84 & 0 & 0 & 9.82 \\
\hline Phillyrea angustifolia & 4.03 & 0 & 0.12 & 0 & 7.90 & 45.77 & 0.37 & 0 & 23.57 \\
\hline Prunus lusitanica & 3.49 & 0 & 0.08 & 0 & 5.57 & 2.22 & 1.10 & 0 & 11.40 \\
\hline Pterospartum tridentatum & 4.02 & 0.02 & 0.48 & 1.32 & 10.58 & 321.46 & 0.87 & 1.65 & 37.80 \\
\hline Rhamnus alaternus & 3.13 & 0.01 & 0.14 & 1.14 & 3.63 & 12.07 & 0.49 & 0.53 & 7.38 \\
\hline Rubus ulmifolius & 4.28 & 0.08 & 0.15 & 0.45 & 5.73 & 122.48 & 0.57 & 0.34 & 18.94 \\
\hline Ruscus aculeatus & 3.57 & 0 & 2.50 & 1.06 & 3.16 & 61.41 & 0 & 0 & 19.85 \\
\hline Ulex minor & 3.41 & 0.09 & 0.34 & 1.33 & 3.17 & 83.41 & 1.05 & 0.20 & 23.63 \\
\hline Viburnum tinus & 3.38 & 0.33 & 0.05 & 0.29 & 7.38 & 112.98 & 1.42 & 0.45 & 36.28 \\
\hline
\end{tabular}

According to the limit values presented in the ENplus ${ }^{\circledR}$ standard, all species meet the requirements for the elements $\mathrm{Co}, \mathrm{Cr}, \mathrm{Mn}, \mathrm{Ni}$ and $\mathrm{Pb}$, with values $\leq 10 \mathrm{mg} / \mathrm{kg}$ for all elements. In the case of $\mathrm{Hg}$, the values detected for all samples were below the detection limit of the equipment used, which was $\leq 0.001 \mathrm{mg} / \mathrm{kg}$, which is why it was considered to be non-existent, or practically non-existent, in all samples. In the case of As, none of the species studied showed values within the range allowed by the ENplus ${ }^{\circledR}$ standard, which is $\leq 1 \mathrm{mg} / \mathrm{kg}$. In the case of $\mathrm{Cd}$, with a limit value $\leq 0.5 \mathrm{mg} / \mathrm{kg}$, only Cistus populifolius, Genista falcata, Halimium lasianthum and Ilex aquifolium presented values outside the permitted limit. For $\mathrm{Cu}$, with a limit value $\leq 10 \mathrm{mg} / \mathrm{kg}$, the species Cistus populifolius, Cistus psilosepalus, Cytisus multiflorus, Daphne gnidium, Erica australis, Halimium lasianthum and Pterospartum tridentatum were outside the permitted limit. In the case of $\mathrm{Zn}$, with a limit value $\leq 100 \mathrm{mg} / \mathrm{kg}$, the species Cistus populifolius and Ilex aquifolium presented values outside the limit. As can be seen, the high content of metallic elements, even the smallest elements, which will be oxidized during the combustion process, indicates a 
high propensity for ash formation, confirmed by the high ash contents determined by the thermogravimetric analysis presented in Section 3.1.

\subsection{Energy Recovery and Fires in Bush and Pasture Areas}

The land use and occupation in mainland Portugal are divided as shown in Table 3, according to data provided by Direção Geral do Território (DGT) for the year 2018.

Table 3. Land use and occupation in mainland Portugal for the year 2018.

\begin{tabular}{cc}
\hline Land Use and Occupation & \% Area \\
\hline Forests & $39 \%$ \\
Scrub land & $12 \%$ \\
Agro-forest land & $8 \%$ \\
Pastures & $7 \%$ \\
Agriculture & $26 \%$ \\
Urban and artificial areas & $5 \%$ \\
Other & $3 \%$ \\
\hline Total & $\mathbf{1 0 0} \%$ \\
\hline
\end{tabular}

As can be seen, $92 \%$ of the national territory is made up of areas where land use is related to agriculture, pastures and forests. From the data presented, it appears that the dominant land-use type is forest with $39 \%$, followed by the land used for agricultural purposes with $26 \%$. However, if we add the areas occupied by scrub land, accounting for $12 \%$, normally located in the peripheral areas of forests, abandoned agricultural land and mountain areas, together with the pastures land with $7 \%$ and the land used for agroforestry practices with $8 \%$, they occupy $27 \%$ of the national territory.

This total area, where small herbaceous, shrub and tree species dominate, except for the southern parts of the country, where agro-silvo-pastoral systems include forests of Quercus suber and Quercus rotundifolia, also plays a very important role in the economic development of the primary sector. In fact, it is often difficult to understand how these areas can make a positive contribution from an economic point of view. On the one hand, while pasture land is used for animal feed and agroforestry surfaces can alternate between animal feed and cereal production, scrub areas do not initially appear to be useful to justify their management and valorization, as the type of use cannot be altered.

These areas of scrub have enormous potential, as they can contribute in various ways to land valorization, namely, through the provision of ecosystem services, such as the preservation of biodiversity, the provision of shelter areas for wildlife, the preservation of areas for the proliferation of pollinating insects such as bees or the protection of soils against wind and water erosion [36]. However, although much less prominent than forest areas, these areas are also consumed by rural fires, and for many years, they have even constituted a greater part of the total burnt area. Figure 15 shows the comparison between the burnt areas occupied by forest and the sum of the areas encompassed by scrub, pastures and agroforestry surfaces, which, here, are called scrub and pasture.

The evolution of rural fires in this type of land has changed significantly in recent years. As can be seen by comparing the areas burnt for forests and for forests and pastures during the 1980s, only in 1988 did rural fires consume a higher area of bushes and pastures $(62 \%)$ than forest (38\%), with this also being the year of the decade in which rural fires consumed the smallest areas of 8627 and 13,807 ha for forest and for bushes and pastures, respectively. The situation was corrected again, although in 1989, there was still a slight difference, with $51 \%$ for the burnt area of scrub and pasture and $49 \%$ for forest. This trend continued until 1993 , with scrub and pasture representing the majority of the burnt area again at $52 \%$, reaching the historical maximum of $84 \%$ of the total burnt area the following year. In 1995, forest returned to constituting the majority at $52 \%$, after which scrub and pasture areas dominated the total burnt area until 2002, with an alternation occurring until 2006. From that year until 2016, the burnt area always corresponded mostly to land occupied with 
scrub and pasture, and in 2017, the year that presented the largest burned area in history, more forest was burned than the scrub and pasture. This alternation between the major types of burnt areas demonstrates the changes in the pattern of occurrences of rural fires, but also the changes caused by the different forms of management of the territory, which will certainly be related to the desertification of the land that occurred during the end of the 1980s in the period following the entry of Portugal into the European Community, which led to the growth of public civil construction works, attracting thousands of workers from rural areas from the interior to the coast, leading the collection practices of bushes for cattle beds and other traditional activities to fall into disuse, as well as to the decrease in herds that controlled the quantities of biomass available. This change in the dynamics of land management has led to the evolution of the characteristics of this type of land use and occupation, both in terms of enhancing space as well as the potential use of resources, namely, the accumulation of excess biomass, increasing the risk of new rural fires.

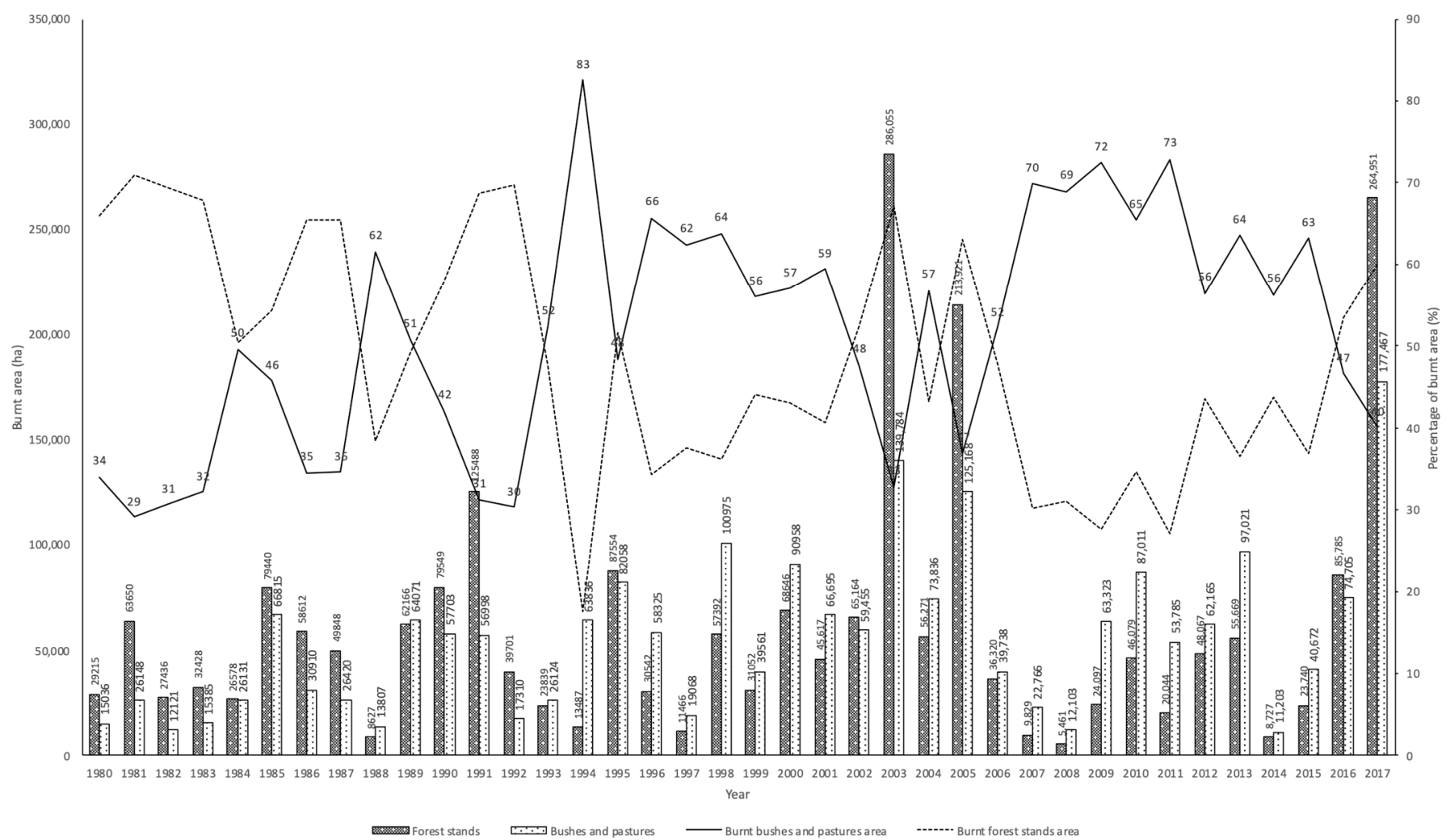

Figure 15. Comparison between burnt areas occupied by forest and by scrub and pasture.

The use of these species in the production of energy, either directly, in biomass plants or indirectly via the production of fuels derived from biomass, presents itself as a possibility that had aroused growing interest, mainly due to the opportunity presented for the recovery of residual biomass [37]. This valorization and use are more important with a greater quantity of materials in use, as this encourages and enhances the use of materials from cleaning and fuel management operations, contributing to the reduction in the risk of the occurrence of rural fires. The energetic valorization of residual biomass is, in fact, the best option to include the materials coming from cleaning and fuel management operations, since it allows for the creation of value chains that contribute to the sustainability of the operations through the attribution of a value to the materials. However, as previously mentioned, this biomass presents several disadvantages, particularly from the point of view of their chemical properties, as widely discussed in the previous sections, but also regarding their heterogeneity and, mainly, their density. In fact, it is this physical property that hinders the logistical process most, since the difficulties caused by transport to the 
point of recovery are reflected in increased costs, which make the attribution of value to waste materials unfeasible. This perspective can be counterbalanced through the creation of biomass logistic centers (BLCs), strategically distributed in order to optimize the collection processes, which allow the concentration of the quantities and types of biomass to be sent for recovery, or even by carrying out pre-processing operations, such as the destruction or drying of materials. Thus, according to Alves et al. (2021), BLCs would be referred to as second-generation biomass logistic centers (2GBLCs), since the materials are subjected to processes where the added value is verified [38].

As seen in the results obtained by the laboratory characterization, these residual materials have many limitations for energy valuation through conventional processes, namely, through direct combustion or inclusion as a raw material for the production of wood pellets or briquettes [39]. However, as already demonstrated in previous studies, the use of these materials to produce wood pellets that are intended for local consumption on a small scale and that are not subject to certification by standards such as ENplus ${ }^{\circledR}$ may create a possibility of enhancing these materials. Their management and control, in order to prevent their accumulation in forest edges and in the land occupied by scrub and pasture, have to be considered as a possibility [40]. However, there are several difficulties involved, as already described, so the study of new valuation possibilities is a priority objective for solving the problem, for example, of the proliferation of rural fires [41]. As an alternative to traditional energy recovery, the use of thermochemical conversion processes, such as torrefaction, pyrolysis or gasification, may be the way forward [42]. In this way, residual materials can be valued through more efficient processes and are more capable of reacting positively to the disadvantages found, since in the current state of the art, the valuation of these residual materials by traditional methods, whether as biomass or in the production of wood pellets, does not appear to be viable.

\section{Conclusions}

Rural fires are a constant threat all over the world, but mainly in territories with Mediterranean climates, such as Portugal, where climate changes have been felt in an intense and progressive way in recent years. The risk of occurrence of rural fires has progressively increased, with the burnt area corresponding to land covered with scrub and pastures taking the lead, already supplanting the forest area. For this reason, the cleaning and management of the fuel load at the edges of forests and on scrub and pasture areas are a priority, especially if this management contributes to the creation of value chains that use these residual materials in the production of energy, or as a raw material to produce biomass-derived fuels. However, as verified by the obtained results, the energetic valorization of these materials does not present itself as an immediate solution given the physicochemical characteristics that the materials present. However, it was also demonstrated that the accumulation of these materials increases the risk of rural fires, so the development of recovery solutions is a priority. Thermochemical conversion processes, such as torrefaction, pyrolysis or gasification, may be alternatives for the valorization of such residual biomass, since the uses that are currently recommended are not viable solutions due the specificities presented by these materials.

Author Contributions: Conceptualization, L.J.R.N. and C.I.R.M.; methodology, L.J.R.N., N.M.C.A.R. and C.J.P.G.; validation, L.J.R.N., M.A.M.R. and C.J.P.G.; formal analysis, L.J.R.N., C.I.R.M. and M.A.M.R.; investigation, L.J.R.N., M.A.M.R., C.I.R.M., C.J.P.G. and N.M.C.A.R.; resources, L.J.R.N.; data curation, L.J.R.N., M.A.M.R. and C.I.R.M.; writing-original draft preparation, L.J.R.N., M.A.M.R and C.I.R.M.; writing-review and editing, L.J.R.N., M.A.M.R., C.I.R.M., C.J.P.G. and N.M.C.A.R.; supervision, N.M.C.A.R. and C.J.P.G.; project administration, N.M.C.A.R. and C.J.P.G. All authors have read and agreed to the published version of the manuscript.

Funding: L.J.R.N. was supported by Prometheus-Research Unit on Energy, Materials and Environment for Sustainability, UIDP / 05975/2020, funded by national funds through FCT—Fundação para a Ciência e Tecnologia. 
Institutional Review Board Statement: Not applicable.

Informed Consent Statement: Not applicable.

Data Availability Statement: The data presented in this study are available on request to the corresponding author.

Acknowledgments: The authors would like to thank the group of forest sappers from Manteigas for their support in opening access to the site under study, and the União de Freguesias de Vide e Cabeça for their support during the entire investigation.

Conflicts of Interest: The authors declare no conflict of interest.

\section{References}

1. Sivakumar, B. Global climate change and its impacts on water resources planning and management: Assessment and challenges. Stoch. Environ. Res. Risk Assess. 2011, 25, 583-600. [CrossRef]

2. Weingart, P.; Engels, A.; Pansegrau, P. Risks of communication: Discourses on climate change in science, politics, and the mass media. Public Underst. Sci. 2000, 9, 261-284. [CrossRef]

3. Johnson, J.M.-F.; Franzluebbers, A.J.; Weyers, S.L.; Reicosky, D.C. Agricultural opportunities to mitigate greenhouse gas emissions. Environ. Pollut. 2007, 150, 107-124. [CrossRef]

4. Sharifzadeh, M.; Triulzi, G.; Magee, C.L. Quantification of technological progress in greenhouse gas (GHG) capture and mitigation using patent data. Energy Environ. Sci. 2019, 12, 2789-2805. [CrossRef]

5. Retallack, G. Soils and global change in the carbon cycle over geological time. Treatise Geochem. 2003, 5, 605.

6. Arthur, M.A.; Dean, W.E.; Schlanger, S. Variations in the global carbon cycle during the Cretaceous related to climate, volcanism, and changes in atmospheric $\mathrm{CO}_{2}$. Carbon Cycle Atmos. $\mathrm{CO}_{2}$ Nat. Var. Archean Present 1985, 32, 504-529.

7. Berner, R.A. The carbon cycle and carbon dioxide over Phanerozoic time: The role of land plants. Philos. Trans. R. Soc. Lond. Ser. B Biol. Sci. 1998, 353, 75-82. [CrossRef]

8. Kim, D.; Lee, K.; Park, K.Y. Upgrading the characteristics of biochar from cellulose, lignin, and xylan for solid biofuel production from biomass by hydrothermal carbonization. J. Ind. Eng. Chem. 2016, 42, 95-100. [CrossRef]

9. Ribeiro, J.M.C.; Godina, R.; Matias, J.C.d.O.; Nunes, L.J.R. Future perspectives of biomass torrefaction: Review of the current state-of-the-art and research development. Sustainability 2018, 10, 2323. [CrossRef]

10. Miranda, T.; Arranz, J.; Montero, I.; Román, S.; Rojas, C.; Nogales, S. Characterization and combustion of olive pomace and forest residue pellets. Fuel Process. Technol. 2012, 103, 91-96. [CrossRef]

11. Proto, A.R.; Palma, A.; Paris, E.; Papandrea, S.F.; Vincenti, B.; Carnevale, M.; Guerriero, E.; Bonofiglio, R.; Gallucci, F. Assessment of wood chip combustion and emission behavior of different agricultural biomasses. Fuel 2021, 289, 119758. [CrossRef]

12. Granados, D.; Velásquez, H.; Chejne, F. Energetic and exergetic evaluation of residual biomass in a torrefaction process. Energy 2014, 74, 181-189. [CrossRef]

13. Álvarez-Álvarez, P.; Pizarro, C.; Barrio-Anta, M.; Cámara-Obregón, A.; Bueno, J.L.M.; Álvarez, A.; Gutiérrez, I.; Burslem, D.F. Evaluation of tree species for biomass energy production in Northwest Spain. Forests 2018, 9, 160. [CrossRef]

14. McKendry, P. Energy production from biomass (part 1): Overview of biomass. Bioresour. Technol. 2002, 83, 37-46. [CrossRef]

15. d'Angelo, M.; Enne, G.; Madrau, S.; Percich, L.; Previtali, F.; Pulina, G.; Zucca, C. Mitigating land degradation in Mediterranean agro-silvo-pastoral systems: A GIS-based approach. Catena 2000, 40, 37-49. [CrossRef]

16. Pardini, A.; Nori, M. Agro-silvo-pastoral systems in Italy: Integration and diversification. Pastor. Res. Policy Pract. 2011, 1, 1-10. [CrossRef]

17. van Doorn, A.M.; Correia, T.P. Differences in land cover interpretation in landscapes rich in cover gradients: Reflections based on the montado of South Portugal. Agrofor. Syst. 2007, 70, 169-183. [CrossRef]

18. Telmo, C.; Lousada, J. Heating values of wood pellets from different species. Biomass Bioenergy 2011, 35, 2634-2639. [CrossRef]

19. Nunes, L.; Matias, J.C.; Catalao, J.P. Wood pellets as a sustainable energy alternative in Portugal. Renew. Energy 2016, 85, 1011-1016. [CrossRef]

20. Fernandes, G.; Almeida, H. Cooperation and Competitiveness in Tourism Sustainability. Positioning of Tourist Actors in the Serra da Estrela Natural Park in Portugal. In Proceedings of the International Conference on Tourism, Technology and Systems, Cartagena, Colombia, 29-31 October 2020; pp. 52-65.

21. Vieira, G. Combined numerical and geomorphological reconstruction of the Serra da Estrela plateau icefield, Portugal. Geomorphology 2008, 97, 190-207. [CrossRef]

22. Mora, C. A synthetic map of the climatopes of the Serra da Estrela (Portugal). J. Maps 2010, 6, 591-608. [CrossRef]

23. Vieira, G.; de Castro, E.; Gomes, H.; Loureiro, F.; Fernandes, M.; Patrocínio, F.; Firmino, G.; Forte, J. The Estrela Geopark-From Planation Surfaces to Glacial Erosion. In Landscapes and Landforms of Portugal; Springer: Berlin/Heidelberg, Germany, 2020; pp. 341-357.

24. Silva, V.; Catry, F.X.; Fernandes, P.M.; Rego, F.C.; Paes, P.; Nunes, L.; Caperta, A.D.; Sérgio, C.; Bugalho, M.N. Effects of grazing on plant composition, conservation status and ecosystem services of Natura 2000 shrub-grassland habitat types. Biodivers. Conserv. 2019, 28, 1205-1224. [CrossRef] 
25. Turner, C.; Hannon, G. Vegetational evidence for late Quaternary climatic changes in southwest Europe in relation to the influence of the North Atlantic Ocean. Philos. Trans. R. Soc. Lond. Ser. B Biol. Sci. 1988, 318, 451-485.

26. Ruiz-Labourdette, D.; Schmitz, M.F.; Pineda, F.D. Changes in tree species composition in Mediterranean mountains under climate change: Indicators for conservation planning. Ecol. Indic. 2013, 24, 310-323. [CrossRef]

27. Van der Knaap, W.; Van Leeuwen, J. Holocene vegetation succession and degradation as responses to climatic change and human activity in the Serra de Estrela, Portugal. Rev. Palaeobot. Palynol. 1995, 89, 153-211. [CrossRef]

28. Van der Knaap, W.; Van Leeuwen, J. Late Glacial and early Holocene vegetation succession, altitudinal vegetation zonation, and climatic change in the Serra da Estrela, Portugal. Rev. Palaeobot. Palynol. 1997, 97, 239-285. [CrossRef]

29. Vessella, F.; López-Tirado, J.; Simeone, M.C.; Schirone, B.; Hidalgo, P.J. A tree species range in the face of climate change: Cork oak as a study case for the Mediterranean biome. Eur. J. For. Res. 2017, 136, 555-569. [CrossRef]

30. Marques, E.; Paiva, J.M.; Pinho, C. The new Portuguese energy challenge? Pellets from shrubs. In Proceedings of the 21 st Brazilian Congress of Mechanical Engineering, Cuiabá, Brazil, 24-28 October 2011; p. 12.

31. Marques, E.; Ferreira, T.; Pereira, C.; Paiva, J.M.; Pinho, C. Analysis of kinetic and diffusive data from the combustion of char pellets made with hybrid mixtures. Energy 2019, 181, 1179-1188. [CrossRef]

32. Shan, L.; Kong, M.; Bennet, T.D.; Sarroza, A.C.; Eastwick, C.; Sun, D.; Lu, G.; Yan, Y.; Liu, H. Studies on combustion behaviours of single biomass particles using a visualization method. Biomass Bioenergy 2018, 109, 54-60. [CrossRef]

33. Nunes, L.J.; Rodrigues, A.M.; Loureiro, L.M.; Sá, L.C.; Matias, J.C. Energy Recovery from Invasive Species: Creation of Value Chains to Promote Control and Eradication. Recycling 2021, 6, 21. [CrossRef]

34. Hawkesford, M.J. Plant responses to sulphur deficiency and the genetic manipulation of sulphate transporters to improve S-utilization efficiency. J. Exp. Bot. 2000, 51, 131-138. [CrossRef]

35. Rodrigues, A.; Nunes, L. Evaluation of ash composition and deposition tendencies of biomasses and torrefied products from woody and shrubby feedstocks: SRC poplar clones and common broom. Fuel 2020, 269, 117454. [CrossRef]

36. Guerra, C.A.; Metzger, M.J.; Maes, J.; Pinto-Correia, T. Policy impacts on regulating ecosystem services: Looking at the implications of 60 years of landscape change on soil erosion prevention in a Mediterranean silvo-pastoral system. Landsc. Ecol. 2016, 31, 271-290. [CrossRef]

37. Jeong, J.S. Biomass Feedstock and Climate Change in Agroforestry Systems: Participatory Location and Integration Scenario Analysis of Biomass Power Facilities. Energies 2018, 11, 1404. [CrossRef]

38. Alves, D.N.; Míguez Tabarés, J.L.; Rivo-Lopez, E.; Saavedra, A.; Fariña, M.E.; Alonso, J.M.; Nunes, L.J. Residual forest biomass and energy assessment: A case study analysis in the region of Alto Minho (North Portugal) for the creation of BLCs and 2GBLCs. Int. J. Sustain. Energy 2021, 1-18. [CrossRef]

39. Iakovou, E.; Karagiannidis, A.; Vlachos, D.; Toka, A.; Malamakis, A. Waste biomass-to-energy supply chain management: A critical synthesis. Waste Manag. 2010, 30, 1860-1870. [CrossRef]

40. Filipe dos Santos Viana, H.; Martins Rodrigues, A.; Godina, R.; Carlos de Oliveira Matias, J.; Jorge Ribeiro Nunes, L. Evaluation of the Physical, Chemical and Thermal Properties of Portuguese Maritime Pine Biomass. Sustainability 2018, 10, 2877. [CrossRef]

41. Nunes, M.C.; Vasconcelos, M.J.; Pereira, J.M.; Dasgupta, N.; Alldredge, R.J.; Rego, F.C. Land cover type and fire in Portugal: Do fires burn land cover selectively? Landsc. Ecol. 2005, 20, 661-673. [CrossRef]

42. Nunes, L.J.; Matias, J.C. Biomass torrefaction as a key driver for the sustainable development and decarbonization of energy production. Sustainability 2020, 12, 922. [CrossRef] 